OPEN ACCESS

Edited by:

Alexandre Mebazaa,

Assistance Publique Hopitaux

De Paris (AP-HP), France

Reviewed by:

Luz Pamela Blanco,

National Institutes of Health (NIH),

United States

Sermin Genc,

Dokuz Eylül University, Turkey

${ }^{*}$ Correspondence:

Serge Grazioli

serge.grazioli@hcuge.ch

Specialty section: This article was submitted to Inflammation,

a section of the journal

Frontiers in Immunology

Received: 19 December 2017 Accepted: 05 April 2018

Published: 04 May 2018

Citation:

Grazioli S and Pugin J (2018) Mitochondrial Damage-Associated

Molecular Patterns: From

Inflammatory Signaling to Human Diseases.

Front. Immunol. 9:832. doi: 10.3389/fimmu.2018.00832

\section{Mitochondrial Damage-Associated Molecular Patterns: From Inflammatory Signaling to Human Diseases}

\author{
Serge Graziolit,2* and Jérôme Pugin ${ }^{3}$ \\ ${ }^{1}$ Pediatric Intensive Care Unit, Department of Pediatrics, University Hospital of Geneva, University of Geneva, Geneva, \\ Switzerland, ${ }^{2}$ Department of Microbiology and Molecular Medicine, Faculty of Medicine, University of Geneva, Geneva, \\ Switzerland, ${ }^{3}$ Intensive Care Unit, Department of Anesthesiology, Faculty of Medicine, University Hospital of Geneva, \\ University of Geneva, Geneva, Switzerland
}

Over the recent years, much has been unraveled about the pro-inflammatory properties of various mitochondrial molecules once they are leaving the mitochondrial compartment. On entering the cytoplasm or the extracellular space, mitochondrial DAMPs (also known as mitochondrial alarmins) can become pro-inflammatory and initiate innate and adaptive immune responses by activating cell surface and intracellular receptors. Current evidence indicates that uncontrolled and excessive release of mitochondrial DAMPs is associated with severity, has prognosis value in human diseases, and contributes to the dysregulated process observed in numerous inflammatory and autoimmune conditions, as well as in ischemic heart disease and cancer. Herein, we review that the expanding research field of mitochondrial DAMPs in innate immune responses and the current knowledge on the association between mitochondrial DAMPs and human diseases.

Keywords: damage-associated molecular pattern, mitochondria, inflammation, pro-inflammatory cytokines, sterile inflammation, alarmins

\section{INTRODUCTION}

Innate immunity represents the first line of defense of the human body against infection. This system can detect pathogens through the recognition of conserved molecular motifs, called pathogen-associated molecular patterns (PAMPs). The bindings of these molecules to pattern recognition receptors (PRRs), such as toll-like receptors (TLRs) and NOD-like receptors (NLRs), activates the immune system and triggers a response against the pathogen. Interestingly, it has been shown in the recent years that the human body is using this same system to signal tissue damage in absence of infection in a theory developed by Matzinger in 2004 (1). Thus, in context of major cellular stress, the cells release intracellular molecules in the extracellular space, acting as a stress signal for the body and named damage-associated molecular patterns (DAMPs or alarmins). Similarly to PAMPs, DAMPs are recognized by PRRs and able to trigger an immune response in various cells such as macrophages, dendritic cells, and neutrophils (2). Prototypical DAMPs include DNA, high-mobility group box 1 (3), or heat shock proteins (4) and are implicated in a growing list of inflammatory diseases.

It has recently been demonstrated that "danger" signals present in the cytoplasm in context of an active infection (PAMPs) or cellular damage (DAMPs) could also be detected by intracellular sensors of the innate immune system either directly or indirectly as a result of loss of homeostasis and trigger a pro-inflammatory immune response through the formation of inflammasomes $(5,6)$. 
Inflammasomes are multimeric protein complexes composed of a PRR, typically the NLR or the absent in melanoma 2 (AIM2) receptors that upon sensing its agonists oligomerizes and recruits the adaptor protein apoptosis-associated speck-like protein with a caspase-activation and recruitment domain (CARD) (ASC) to form a multimeric complex. Oligomerized ASC recruits procaspase- 1 into the complex through CARD-CARD interaction, which then is converted into bioactive caspase- 1 by autoproteolitic cleavage. Biologically active caspase- 1 then processes the pro-inflammatory cytokines pro-IL-1 $\beta$ and pro-IL18 into their bioactive forms (Figure 1) $(7,8)$. For further details, the reader can refer to recent reviews in which all of the NLR inflammasomes have been discussed (9-11).

Recently, mitochondrial DAMPs have been identified as important mediators of the innate immune response and implicated in various conditions such as trauma, sepsis, and autoimmune disorders (Table 1). According to the endosymbiont theory of mitochondria, over a billion years ago, energy producing alpha bacteria were either engulfed by or invaded archezoan cells (12). Thus, the prokaryotic origin of the mitochondria could explain the numerous similarities they share with bacteria including a double membrane structure, an independent genome, which is circular in form, contains significant amount of unmethylated CpG motifs and encodes essential protein subunits of the oxidative phosphorylation system independently of nuclear DNA.

Therefore, it is not really surprising that the release of mitochondrial molecules such as mitochondrial DNA (mtDNA) into the cytosol or the extracellular space triggers such a significant pro-inflammatory response.

To prevent the leak of pro-inflammatory mitochondrial molecules into the cytosol or the extracellular space in context of mitochondrial dysfunction, cells have developed various prevention systems. One of those systems is autophagy that enables cells to recycle damaged mitochondria and prevent leakage of its content into the cytosol or extracellular space.

However, in context of major cellular stress and tissue injury, the system may be overwhelmed, and mitochondrial DAMPS are released into the cytoplasm or the extracellular space, triggering a pro-inflammatory response.

There is a growing body of literature suggesting that mitochondrial DAMPs are implicated in various human diseases (117). Indeed, they are detected in different human body fluids suggesting its potential use as biomarkers for many diseases. The exact mechanism as to how mtDNA is released into the cytosol and the extracellular space is not completely characterized. In addition to a passive release of mtDNA in the context of cellular necrosis or apoptosis, some reports indicate that mitochondria DAMPs such as ATP or mtDNA can be actively secreted into the extracellular space. In these studies, it is suggested a more complex role of the mitochondria as an immunomodulatory of the innate immune system, and a potential therapeutical target for diseases characterized by an uncontrolled inflammation.

Herein, we review the nature and the role of the different mitochondrial DAMPs and discuss their interactions with different organs in the settings of sterile inflammation.

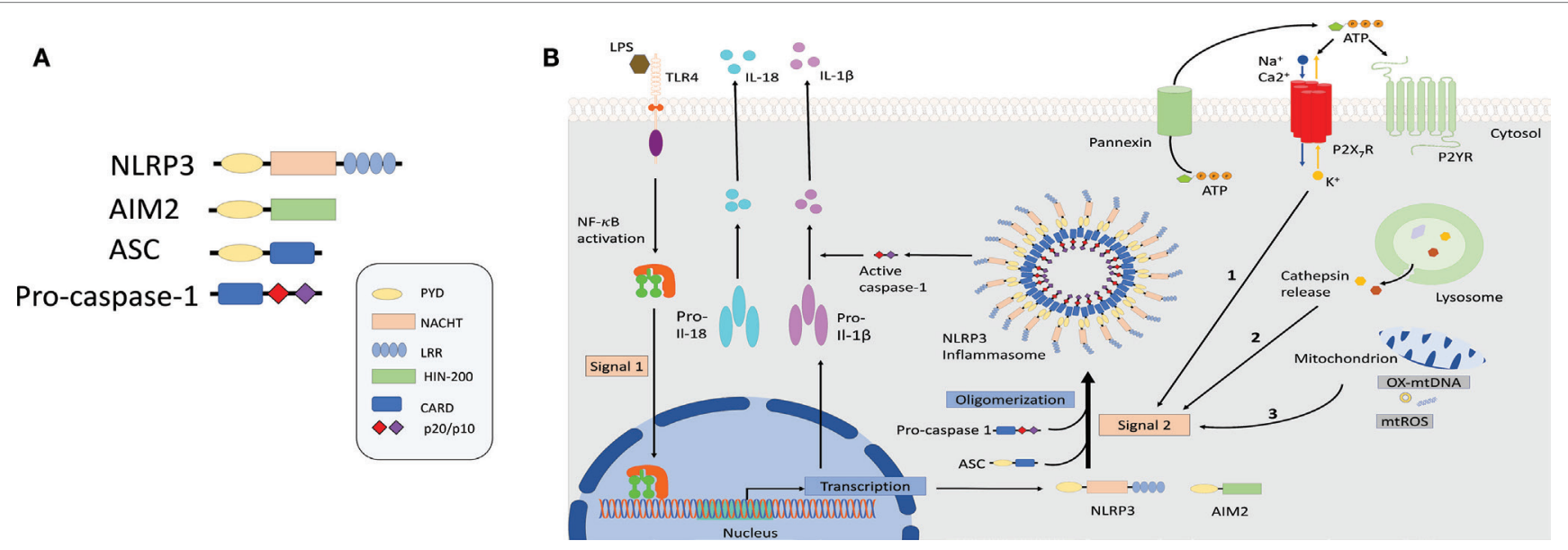

FIGURE 1 | Schematic illustration of selected inflammasome components and mechanism of NLRP3 activation. (A) Shown here is the composition of NLRP3 and absent in melanoma-2 inflammasome sensors as well as the components ASC and caspase-1. (B) NLRP3 inflammasomes activation involves a two-step process: priming and assembly. Signal 1 (priming) is provided by nuclear factor-kB-dependent transcription of pro-interleuking-1 $\beta$ and NLRP3, either through the activation of TLRs or nucleotide-binding oligomerization domain 2 (NOD2) by microbial molecules or endogenous cytokines. The second signal is provided by stimuli that specifically activate NLRP3 and lead to NLRP3 oligomerization, caspase-1 activation followed by the maturation and release of IL-1 $\beta$ and IL-18. Three separate phenomena had been associated with NLRP3 activation. Event 1: ATP mediated ionic flux and intracellular potassium depletion mediated by ATP binding to ligand-gated ion channels $\mathrm{P} 2 \mathrm{X}_{7} \mathrm{R}$. Event 2: cathepsin release following destabilization of lysosomal membrane by sterile particulates, such as silica, asbestos, and cholesterol crystals. Event 3: generation of ROS and cytoplasmic release of mitochondrial DNA following major cellular stress and mitochondrial damage. Abbreviations: ATP, adenosine triphosphate; AIM2, absent in melanoma-2; ASC, apoptosis-associated speck-lick protein containing a CARD; CARD, caspase-

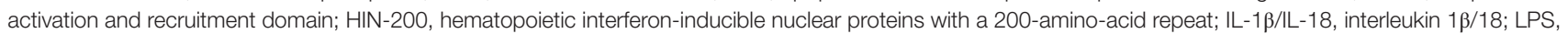
lipopolysaccharide; LRR, leucine-rich repeats; NBD/NACHT, nuclear binding domain; NF-kB, nuclear factor-kB; NLRP3, NLR family pyrin domain-containing; NLR, nucleotide-binding domain and leucine-rich repeat receptors; NOD2, nucleotide-binding oligomerization domain 2; PYD, pyrin domain; ROS, reactive oxygen species; TLRs, toll-like receptors. 
TABLE 1 | Mitochondrial damage-associated molecular patterns.

\begin{tabular}{|c|c|c|c|c|c|}
\hline mtDAMPs & Intracellular physiological role & Extracellular actions & Release pathways & Receptors & Implicated diseases \\
\hline mtDNA & $\begin{array}{l}\text { Coding for oxidative } \\
\text { phosphorylation complex } \\
\text { subunits (mitochondrial proteins) }\end{array}$ & $\begin{array}{l}\text { Pro-inflammatory response; neutrophil activation } \\
(13,14) \text { and NET production (14); increase TLR9 } \\
\text { expression in macrophages (15); endothelial } \\
\text { cells activation (16) promoting neutrophils } \\
\text { adhesion and transmigration }\end{array}$ & $\begin{array}{l}\text { (a) Passive release (via necrosis, } \\
\text { necroptosis (17, 18), apoptosis) } \\
\text { (b) Active release [via mitochondria } \\
\text { derived vesicles (19-22)] }\end{array}$ & $\begin{array}{l}\text { TLR9, inflammasomes } \\
\text { [NLRP3, AIM2 and } \\
\text { NLRC4 (23-25)], } \\
\text { STING (26-28) }\end{array}$ & $\begin{array}{l}\text { Sepsis }(29-37) \text {, trauma }(31,36,38-43) \text {, cardiogenic } \\
\text { shock }(30,44) \text {, cancer }(45-52) \text {, liver failure }(53,54) \text {, } \\
\text { heart failure (55), atherosclerosis }(56) \text {, strokes }(57) \text {, } \\
\text { rheumatoid arthritis }(58,59) \text {, SLE }(60-62)\end{array}$ \\
\hline ATP & $\begin{array}{l}\text { Energy metabolism } \\
\text { and coenzyme }\end{array}$ & $\begin{array}{l}\text { Pro-inflammatory response; neutrophil } \\
\text { chemotaxis, adhesion (63), phagocytosis } \\
(64,65) \text { and degranulation }(66,67) ; \text { monocyte } \\
\text { migration }(68) \text {, adhesion }(69), \text { ROS production } \\
(23,70,71) \text { and phagosome lysosome fusion } \\
\text { (72); Iymphocytes migration (73), activation } \\
\text { (74) and proliferation (63); activation of } \\
\text { NLRP3 inflammasome on monocytes }(75,76)\end{array}$ & $\begin{array}{l}\text { (a) Passive release by necrotic cells } \\
\text { (b) Active secretion by vascular cells } \\
\text { via vesicular exocytosis, and } \\
\text { pannexin channel (77) } \\
\text { (c) Active secretion by epithelial } \\
\text { cells via CFTR dependent (78) } \\
\text { or independent mechanism (79) }\end{array}$ & $\begin{array}{l}\text { Purinergic receptors } \\
\text { (P2X and } \mathrm{P} 2 \mathrm{Y})\end{array}$ & $\begin{array}{l}\text { Cancer }(80,81) \text {, asthma }(82,83) \text {, GVHD (84), lung } \\
\text { diseases }(85,86) \text {, CF }(87)\end{array}$ \\
\hline TFAM & $\begin{array}{l}\text { Regulation of mtDNA } \\
\text { transcription and stabilization }\end{array}$ & $\begin{array}{l}\text { Pro-inflammatory response; synergistic effect } \\
\text { with other mt DAMPs ( } \mathrm{N} \text {-formyl peptide and } \\
\mathrm{mtDNA} \text { ) to increase cytokine production in } \\
\text { monocytes (88) and dendritic cells (89); increase } \\
\text { cytokines production in macrophages (90) }\end{array}$ & (a) Passive release via necrotic cells & Unknown & Heat failure (91), COPD (92) \\
\hline $\begin{array}{l}\mathrm{N} \text {-formyl } \\
\text { peptide (fMLP) }\end{array}$ & $\begin{array}{l}\text { Share similarities with bacterial } \\
\mathrm{N} \text {-formyl peptide }\end{array}$ & $\begin{array}{l}\text { Pro-inflammatory response; chemoattractant } \\
\text { for neutrophils (93) and activates platelets (94) }\end{array}$ & (a) Passive release via necrotic cells & $\begin{array}{l}\text { Formyl peptide } \\
\text { receptors (FPRs) }\end{array}$ & $\begin{array}{l}\text { Trauma with SIRS (95), liver injury (53), localized } \\
\text { juvenile periodontitis (96) }\end{array}$ \\
\hline Succinate & $\begin{array}{l}\text { Intermediate synthetized in } \\
\text { the TCA cycle or metabolite } \\
\text { of cellular respiration }\end{array}$ & $\begin{array}{l}\text { Pro-inflammatory response; triggers } \\
\text { intracellular calcium mobilization, migration } \\
\text { and has synergistic effect with TLRs ligands } \\
\text { for proinflammatory cytokines production in } \\
\text { dendritic cells (97); enhances antigen-specific } \\
\text { activation of helper T lymphocytes; enhances } \\
\text { IL-1 } \beta \text { production in lipopolysaccharide-primed } \\
\text { macrophages (98) }\end{array}$ & Unclear & GPR91 (97) & Pulmonary artery hypertension $(99,100)$ \\
\hline Cardiolipin & $\begin{array}{l}\text { Maintaining membrane potential } \\
\text { and architecture and provides } \\
\text { structural and functional } \\
\text { support to protein involved } \\
\text { in mitochondrial biogenesis }\end{array}$ & $\begin{array}{l}\text { Pro-inflammatory response; activates } \\
\text { inflammasome NLRP3 mediated immune } \\
\text { response (101); activation and proliferation } \\
\text { of gamma/delta T cells (102) }\end{array}$ & & $\begin{array}{l}\text { CD1d (102); NLRP3 } \\
\text { (101), Atp8b1 (103) }\end{array}$ & Pneumonia (103), COPD (104) \\
\hline Cytochrome-c & $\begin{array}{l}\text { electron carrier in mitochondrial } \\
\text { respiratory chain }\end{array}$ & $\begin{array}{l}\text { Pro-inflammatory; cellular toxicity; induced } \\
\text { lymphocytes (105) and neuronal cells (106) } \\
\text { apoptosis }\end{array}$ & $\begin{array}{l}\text { (a) Passive release via necrosis or } \\
\text { apoptosis (107) }\end{array}$ & Apaf-1 (108) & $\begin{array}{l}\text { Myocardial infarction (109), liver diseases (110, } \\
\text { 111), cancer (112, 113), SIRS/MODS (114), acute } \\
\text { encephalopathy (115), hemodialysis (116) }\end{array}$ \\
\hline
\end{tabular}

mtDNA, mitochondrial DNA; NET, neutrophil extracellular trap; TLR9, toll-like receptor 9; NLRP3, NOD, LRR and pyrin domain-containing protein 3; AIM2, absent in melanoma 2; NLRC4, NLR family CARD domain containing 4; STING, stimulator of interferon genes: SLE systemic lupus erythematosus: CFTR, cystic fibrosis transmembrane conductance regulator: ATP, adenosine triphosphate; TFAM, mitochondrial transcription factor A; COPD, chronic obstructive pulmonary disease; SIRS, systemic inflammatory response syndrome; MODS, multiple organ dysfunction syndrome; Apaf-1, apoptotic protease activating factor-1. 


\section{MITOCHONDRIAL DAMPs: FUNCTION AND REGULATION}

\section{Mitochondrial DNA}

Mitochondrial DNA contains 37 genes coding for 2 ribosomal nucleic acids, 22 transfer RNAs, and 13 essential protein subunits of the oxidative phosphorylation system $(118,119)$. Specific characteristics of mtDNA are low methylation levels and heightened susceptibility to oxidative damage. To protect itself from oxidative damage, mtDNA is packaged into protein-DNA complexes called nucleoids under the control of the transcription factor A (TFAM). There are hundreds to thousands copies of mtDNA present in every cell of the human body with the exception of erythrocytes that lack mitochondria.

Mitochondrial DNA can be recognized by three important PRRs of the innate immune system, TLR9, cytosolic inflammasomes, and type I interferon response, and interactions of mtDNA with its receptors trigger a pro-inflammatory response (Figure 2).

\section{MtDNA and TLR9}

TLR9 is a member of the TLR family and is expressed mostly in immune cells including dendritic cells, macrophages, and naturel killer cells. TLR9 is widely referred as a DNA-sensing PRRs since it is able to detect hypomethylated CpG motifs of DNA present in both bacterial $(120,121)$ and viral DNA (122). Experimental studies on human macrophages and dendritic cells stimulated with labeled CpG DNA have demonstrated that CpG DNA is internalized into the lysosomal compartment followed by rapid translocation of TLR9 from its initial location in the endoplasmic reticulum to the $\mathrm{CpG}$-rich lysosomal compartment for ligand binding and signal transduction (123). After the binding of TLR9 and its ligand, numerous downstream pathways will be activated, including pro-inflammatory nuclear factor kappa $\mathrm{B}(\mathrm{NF}-\kappa \mathrm{B})$, nucleotide-binding domain, and leucine-rich repeat (NLR) prying domain containing 3 (NLRP3) inflammasomes, and interferon regulatory factor-dependent type 1 IFN (124).

Due to its similarities with bacteria DNA, it is postulated that mtDNA can mediate a pro-inflammatory response dependent on the TLR9 pathway. This postulate was confirmed by substantial cellular and animal studies demonstrating capacity of mtDNA to activate the inflammatory/immune system via the TLR9 pathway. mtDNA injection in mice causes severe inflammatory response in the lungs $(13,125)$, which was reduced in $t$ tr $9-/-$ and $M y D 88$ $-/-$ mice (125). In another study, using an animal model of acetaminophen-induced liver injury, oral acetaminophen administration to mice induced the release of mtDNA into the circulation and caused a marked systemic pro-inflammatory response with both liver injury and remote lung injury, which was prevented by TLR9 absence (tlr9-/- mice) (53). These animal studies confirmed that mtDNA activates innate immune response though TLR9 with an improvement of outcome when the TLR9 gene is deleted.

\section{mtDNA and TLR9 p38 Mitogen-Activated Protein Kinases (MAPK) Pathway}

Zhang et al. reported that mtDNA was released into the circulation during shock, both in humans and animal model of shock, activated human neutrophils p38 MAPK pathway, and triggered the release of MMP-8 and MMP-9 via TLR9 (38). More recently, $\mathrm{Gu}$ et al. (126) demonstrated that intratracheal instillation of mtDNA in mice activated p38 MAPK via TLR9 and caused significant lung inflammation with histological signs of acute lung injury accompanied by $\mathrm{CD}^{+} 8^{+}$macrophages infiltration.

\section{mtDNA and Neutrophil Extracellular Traps (NETs)}

Neutrophil extracellular traps are extracellular structure secreted by neutrophils that are composed of DNA and able to bind and kill microorganisms. Recent studies in trauma patients have shown that mtDNA was present in NETs and was able to induce NET formation in stimulated human neutrophils via TLR9 independently of NADPH oxidase (14).

\section{mtDNA and Inflammasome}

In addition of its role as DAMPs in the extracellular space, several reports have shown that mtDNA also mediates inflammatory responses in the intracellular space through inflammasomes activation. Several types of inflammasomes have been described with the NOD, leucine-rich repeats, and pyrin domain-containing protein 3 (NLRP3) and AM2 being the inflammasomes the most involved in mtDNA sensing.

\section{mIDNA and NLRP3}

The best characterized inflammasome, NLRP3, is composed of three key components: NLRP3, the ASC, and caspase-1 (Figure 1). For NLRP3 inflammasome to be assembled and activated, two signals are required: a priming signal that is necessary for the upregulation of both NLRP3 and pro-Il-1 $\beta$ transcription, often via NF- $\kappa \mathrm{B}$ activation by a TLR or NOD2 agonist such as lipopolysaccharide (LPS), followed by an activation signal produced by crystals, aggregated $\beta$-amyloid, extracellular ATP, or microbial toxins that prompts NLRP3 to assemble the inflammasome complex $(127,128)$.

Nakahira et al. and Zhou et al. $(23,129)$ were the first to demonstrate a link between mitochondrial dysfunction and NLRP3 inflammasome activation. They showed that mtDNA mediates inflammatory response in the intracellular space though the activation of caspase- 1 in response to LPS and ATP in bone marrow-derived macrophages (BMDM). Further, they demonstrated that mitochondrial ROS was required, upstream of mtDNA, for caspase-activation upon LPS and ATP treatment. Interestingly, they also found that NLRP3 inflammasome could increase cytosolic mtDNA release, which could play a role as a positive feedback loop, and further increase the pro-inflammatory response. Shimada et al. further characterized mtDNA and NLRP3 inflammasome interaction by showing that induction of mitochondrial damage in macrophages triggered an apoptotic signal that caused the cytosolic release of oxidized mtDNA that binds to and activated NLRP3 inflammasome (24).

\section{mtDNA and AIM2}

Absent in melanoma-2 represents another well described cytoplasmic DNA sensor. It belongs to the IFI20X-IFI16 (PYHIN) protein family and binds to DNA via hematopoietic interferoninducible nuclear proteins with a 200-amino-acid repeat domain (130), whereas the pyrin domain associates with the adaptor molecules ASC to activate caspases $(131,132)$. 


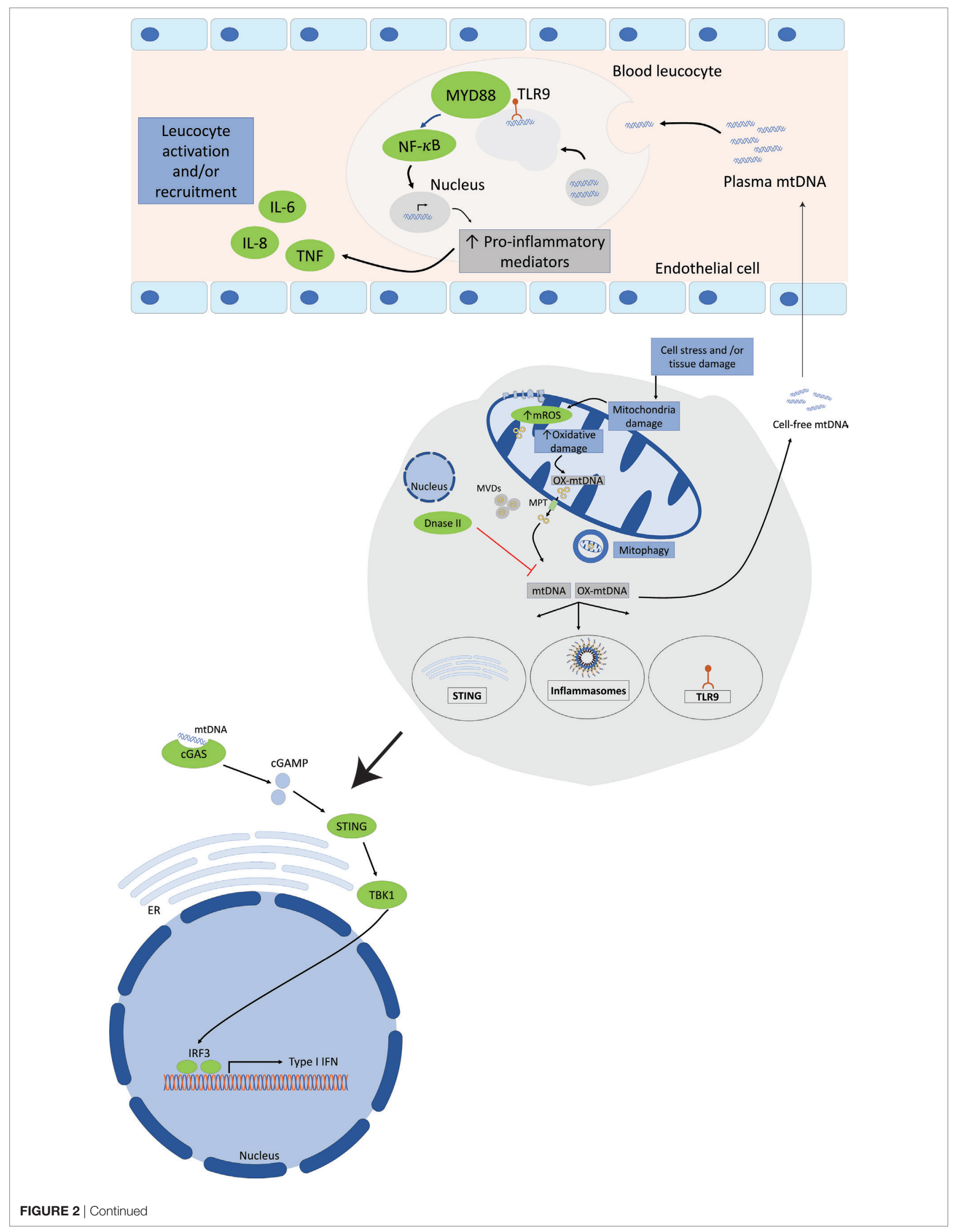


FIGURE 2 | Mitochondrial DNA (mtDNA) mediates a pro-inflammatory response by interacting with TLR9, cytosolic inflammasomes, and type I interferon response. Tissue injury or cellular damage can cause mitochondrial dysfunction resulting in oxidative damage with increased mitochondrial reactive oxygen species (ROS) production and mtDNA oxidation. Oxidized mtDNA will be released into the cytosol and then to the extracellular milieu by various mechanisms including the transport in mitochondrial derived vesicles (MVDs) or through mitochondrial permeability transition pores (MPT). The whole damaged mitochondria can also be recycled through the mitophagy process. In the plasma, mtDNA activates TLR9-mediated signaling pathway in circulating neutrophils resulting in increased production of pro-inflammatory mediators, such as tumor necrosis factor (TNF), interleukin-6 (IL-6), and adhesion molecules. Cytosolic mtDNA can also engage and activate the NOD, leucine-rich repeats, and pyrin domain-containing protein 3 (NLRP3) inflammasome or absent in melanoma 2 inflammasome and trigger a pro-inflammatory response in cells primed with first signal in inflammasome activation through the nuclear factor (NF)-kB pathway. Finally, cytosolic mtDNA can also be recognized by and engage the cyclic GMP-AMP synthase (cGAS). Once activated cGAS triggers conformational changes of the endoplasmic reticulum-resident protein stimulator of interferon genes (STING), which engages TANK-binding kinase 1 to activate interferon regulatory factor 3 (IRF3) and/or IRF7 to stimulate transcription of type I interferons (IFNs) genes.

The groups of Nakahira et al. (23) and Shimada et al. (24) both showed that BMDM transfected with mtDNA and exposed to LPS and ATP had an increase in IL- $1 \beta$ production through a predominant AIM2 inflammasome activation. Recently, Yu et al. (133) were able to bring further clarification into the complex interaction between mitochondrial dysfunction, NLRP3 and the activation of AIM2 inflammasomes. They demonstrated that capsase-1-dependent mitochondrial damage represented a critical step in inflammasome activation. In addition, they showed that AIM2 inflammasome activation in BMDM causes caspase-1-dependent mitochondria damage and mitophagy inhibition, which represents cellular process to remove damaged mitochondria. Those studies confirmed that mitochondrial damage represented a critical step in inflammasome activation, with a potential role of mtDNA as direct ligand for NLRP3 and AIM2 inflammasome.

\section{mtDNA and Type I Interferon Response}

Recent reports have shown that mtDNA could also be recognized by another DNA sensing pathway of the innate immune system, namely, the cyclic GMP-AMP synthase (cGAS) and stimulator of interferon genes (STING) axis $(26,27)$ that trigger a type I interferon (IFN) response. cGAS-STING signaling axis represents an important regulator of type I IFN response of both exogenous and endogenous DNA (134-136). cGAS is a cytosolic DNA sensor that activates innate immune response through production of the second messenger cGAMP, which will activate the adaptor STING and induce type I IFN expression (IFN- $\alpha$ and IFN- $\beta$ ). After secretion, type I IFNs will bind to the type I IFN receptor (IFNAR), which will induce the expression of hundreds of interferon-stimulated genes providing a cellular state of viral resistance (137). The groups of Rongvaux et al. (26) and White et al. (27) have both demonstrated that Bax- and Bak-mediated mitochondrial apoptosis caused the release of mtDNA into the cytosol, which is recognized by the cGAS/STING pathway, and trigger a pro-inflammatory response with type I IFN induction in the absence of the apoptotic caspases.

These results suggest that the apoptotic cascade play a critical role to render mitochondrial apoptosis immunologically silent by suppressing DAMP signaling, such as mtDNA.

\section{Mechanism for mtDNA Release to the Cytosol and Extracellular Compartments}

Various mechanisms had been described to explain mtDNA release from the mitochondrial compartment into the cytosol. Several studies demonstrated the transfer of mtDNA from to the cytosol via mitochondrial membrane permeability transition (MPT). One of the first description of the MPT dates from the late 1970s when Haworth and Hunter showed in a series of publications (138-140) that $\mathrm{Ca}^{2+}$ uptake stimulated significant changes in mitochondrial morphology and functional activity mediated by the opening of a non-specific pore in the inner mitochondrial membrane. It is speculated that MPT are constituted of the association of several proteins located at contact sites between the inner and outer mitochondrial membranes (OMMs). Patrushev et al. (141) confirmed those results by demonstrating that MPT induction with exposition to inorganic phosphate trigger the release of mtDNA fragments without disturbing mitochondrial membrane integrity, in a process that was suppressed by cyclosporine treatment, an inhibitor of pore opening. Studies have shown that mitochondrial ROS were involved and could induce MPT. Interestingly, Nakahira et al. (23) have found in their study on mtDNA-induced NLPR3 inflammasome activation, that cotreatment with cyclosporine A was able to inhibit the secretion of IL- $1 \beta$ by macrophages exposed to LPS and ATP suggesting that the cytosolic release of mtDNA in their model was through increased MPT. In a recent publication, West et al. (28) demonstrated that an alteration in the mtDNA packaging system in the mitochondria could cause mtDNA to escape into the cytosol and be detected by the cGAS-STING signaling axis.

A significant side effect of mitochondrial electron transport is the generation of ROS that may oxidize mitochondrial protein with the risk to jeopardize the integrity and the function of the mitochondria. Recent studies have shown that mitochondria are able to remove oxidized proteins and lipids through small size vesicles, named mitochondria-derived vesicles (MDVs) targeting either peroxisomes (142) or lysosomes (143-146). Interestingly, they demonstrated that MDV delivery to the lysosomes requires PTEN-induced putative kinase-1 (pink1) and parkin in a pathway that was independent of the autophagy (mitophagy) machinery and did not require mitochondrial depolarization (144, 145). Since pink1 and parkin play a major role in the mitophagy process, those results suggest that the two proteins may also be involved in the removal of selected, oxidized cargo, in a process that run in parallel and maybe at an earlier time point than mitophagy. Whether oxidized mtDNA are transported in MDVs and how this new type of mitochondrial quality control mechanism prevents mtDNA-induced pro-inflammatory response remains unclear.

Although cellular necrosis with plasma membrane rupture constitutes a well described mechanism for the extracellular release of DAMPs, including mtDNA, some recent studies have 
shown that mtDNA could be released by cells undergoing a new described form of cellular death called necroptosis $(17,147,148)$. Necroptosis represents a form of programmed necrosis that can be induced via death receptors, such as Fas or tumor necrosis factor-alpha (TNF) receptor leading to the activation of the receptor-interacting protein kinase 1 or 3 (RIP1/RIP3) (149-151). In an in vitro model of necroptosis, Maeda et al. (147) demonstrated that intact mitochondria were released by Jurkat cells and murine fibroblasts after TNF- $\alpha$ induced necroptosis before the disruption of the plasma membrane and could be sensed and phagocytosed by human macrophages, triggering the release of pro-inflammatory cytokines. Further supporting the active extracellular release of mitochondria and mitochondria components, experimental studies have shown that mitochondria could be actively transferred from bone-marrow-derived stroma cells to alveolar epithelial cells (19) and induce protection against acute lung injury or rescue aerobic respiration (20). Interestingly, Boudreau et al. (152) found that activated platelets secrete functional intact mitochondria into the extracellular space as free organelles or incorporated into microparticles. They showed that released mitochondria could be hydrolyzed by phospholipase A2-IIA-releasing mitochondrial DAMPs, including mtDNA, thus promoting leukocytes activation.

In a recent study, Caielli et al. brought some insights on the mechanism regulating mtDNA extracellular release in neutrophils (60). First, they demonstrated that neutrophils are spontaneously releasing mtDNA in the extracellular milieu in absence of cell death or membrane disruption, in a process enhanced by TLR7 engagement. Second, they showed that unlike other immune cells, neutrophils treated with CCCP to depolarize mitochondrial membrane are unable to complete the mitophagy process, suggesting that mtDNA extrusion may represent an alternative for the cell to remove oxidized mtDNA produced by damaged mitochondria. In addition, they observed that, in unstimulated neutrophils, oxidized mtDNA dissociated from TFAM and was exported into the cytosol in MVDs for lysosomal degradation. However, once the neutrophils are activated with IFN/ $\alpha$ RNP, the dissociation of mtDNA-TFAM does not occur, impairing the clearance of oxidized mtDNA, resulting in the extracellular release of mtDNA still bond to TFAM.

\section{Removal of mtDNA From the Cells}

To prevent the leakage of the highly pro-inflammatory mtDNA both into the cytosol and the extracellular milieu, various cellular mechanisms have been described for the removal of mtDNA and damaged mitochondria. Autophagy, already mentioned in this review, represents a well described cellular mechanism for the removal of damaged organelles and is defined as mitophagy for the specific removal of damaged mitochondria. Numerous studies have demonstrated that blockade of autophagy results in the accumulation of dysfunctional mitochondria in the cells with increase mitochondrial ROS production and cytosolic release of mtDNA with NLRP3 activation $(23,153)$.

DNase II is an acid DNAse found in lysosome that plays an essential role in the degradation of DNA in apoptotic cells by macrophages after phagocytosis (154). Studies have shown that DNAse II plays a major role in mtDNA degradation during autophagy $(55,154)$. In an animal model of pressure overloadedinduced heart failure, Oka et al. (55) demonstrated that in mice lacking DNAse II, pressure overload resulted in mtDNA accumulation in autolysosomes leading to TLR9-induced proinflammatory response in cardiomyocytes.

\section{Mitochondrial RNA}

Just like DNA, bacterial RNA constitutes other potent PAMP that is able to trigger an innate immune response. Numerous studies have demonstrated that bacterial RNA can be detected by cell type-specific endosomal and cytoplasmic receptors (155-159). In both human and murine plasmacytoid dendritic cells, bacterial RNA induces type I IFN response mediated by TLR7 (159), while in human monocytes bacterial RNA is detected by TLR 8 resulting in IL-6 and TNF secretion (160). Interestingly, it has been shown that all three types of bacterial RNA (messenger RNA, transfer RNA, and ribosomal RNAs) were able to activate the NLRP3 inflammasome in human macrophages resulting in caspase1 -mediated cleavage of pro-IL- $1 \beta$ and pro-IL-18 into their active form (161). In a recent publication (160), Krüger et al. have demonstrated that specific mitochondrial ribosomal RNA segments similarly to bacterial ribosomal RNA could be detected by TLR8 receptors of PBMCs inducing a pro-inflammatory response with Il-6 and TNF secretion. Thus, those recent findings reinforce the endosymbiotic theory of mitochondrial origin and highlight a new intracellular alarm signal that can interact with the innate immune system and trigger a pro-inflammatory response.

\section{Adenosine Triphosphate (ATP)}

Adenosine triphosphate is a nucleotide that has the particularity to play two distinct roles in the intracellular and in the extracellular spaces. ATP constitutes the main source of energy for most cellular processes. It is produced in mitochondria through the activation of the glycolysis pathway and the tricarboxylic acid (TCA) cycle. When found in the extracellular space, ATP plays a key role in cell signaling, as well as in the regulation in renal blood flow, vascular endothelium, and inflammatory responses. Moreover, it has been demonstrated that ATP released by injured or dying cells served as a DAMP to alert the immune system of tissue damage binding to a $\mathrm{P} 2$ purinergic receptors. ATP release seems to play key roles in interglia afferent signaling (including pain), in the regulation of renal blood flow, vascular endothelium, and in inflammatory responses. When ATP is released into the extracellular space, it constitutes important signaling molecules that has been involved in numerous inflammatory disorders by binding to purinergic $\mathrm{P} 2$ receptors. $\mathrm{P} 2$ purinergic receptors have a widespread expression throughout different tissues and are subdivided into P2Y receptors (P2YR) that are G-protein-coupled receptors and $\mathrm{P} 2 \mathrm{X}$ receptors $(\mathrm{P} 2 \mathrm{XR})$, which are ligand-gated ion channels (Figure 1).

\section{ATP and P2Y2R Signaling}

Among all the P2YR receptors, $\mathrm{P} 2 \mathrm{Y}_{2} \mathrm{R}$ signaling is the most studied and best characterized. A striking point that came out from all those studies is the complex and ambivalent effect that $\mathrm{P} 2 \mathrm{Y}_{2} \mathrm{R}$ signaling can mediate, depending on the environment. On one hand, $\mathrm{P} 2 \mathrm{Y}_{2} \mathrm{R}$ activation improves mucociliary clearance, 
bacterial clearance, and wound healing, but on the other hand, it contributes to a pro-inflammatory response in context of asthma et skin hypersensitivity (Figure 3).

Initially studied in cystic fibrosis patients because of the positive effect of $\mathrm{P} 2 \mathrm{Y}_{2} \mathrm{R}$ agonists on mucociliary clearance mediated by the inhibition of the epithelial sodium channel ENaC (162), new studies reported the involvement of $\mathrm{P} 2 \mathrm{Y}_{2} \mathrm{R}$ signaling in wound healing. It has been shown that ATP is released from apoptotic cells into the extracellular milieu through plasma membrane channel pannexin 1 and will act as a find-me signal that will bind to $\mathrm{P} 2 \mathrm{Y}_{2} \mathrm{R}$ of macrophages and promote phagocytosis $(163,164)$. Further reports suggested a benefic effect of ATP in bacterial clearance based on neutrophil-dependent ATP release and autocrine activation of $\mathrm{P} 2 \mathrm{Y}_{2} \mathrm{R}$ signaling (165). However, some other studies demonstrated that extracellular ATP contributes to a pro-inflammatory response through $\mathrm{P}_{2} \mathrm{Y}_{2} \mathrm{R}$. It has been shown that $\mathrm{P} 2 \mathrm{Y}_{2} \mathrm{R}$ stimulation with ATP induces the release of proallergic mediators such as IL-33, IL-8, and the eosinophil cationic protein (ECP) by human eosinophils and airway epithelial cells followed by a Th2-type innate immune response in mice exposed to allergens $(82,166)$.

\section{ATP and P2X7 Signaling}

$\mathrm{P} 2 \mathrm{X}$ receptors are ligand-gated ion channels of which seven subtypes have been characterized (P2X1-7). Unlike P2YR, which can bind different ligands (ATP, ADP, UTP, UDP), P2XRs respond primarily to extracellular ATP. Binding to P2XR allow sodium and calcium influx and potassium efflux resulting in activations of p38 MAPK or phospholipase A2 mediated by the increased intracellular calcium level (167). Among all the P2XR subtypes, $\mathrm{P} 2 \mathrm{X} 7$ receptors appears to be a key players in various inflammatory and infectious diseases and is capable of activating NLRP3 inflammasome (168) (Figure 3).

Indeed, several studies $(72,169,170)$ demonstrated that ATP plays a major role in the innate immune response against intracellular bacterial infection such as tuberculosis or toxoplasmosis

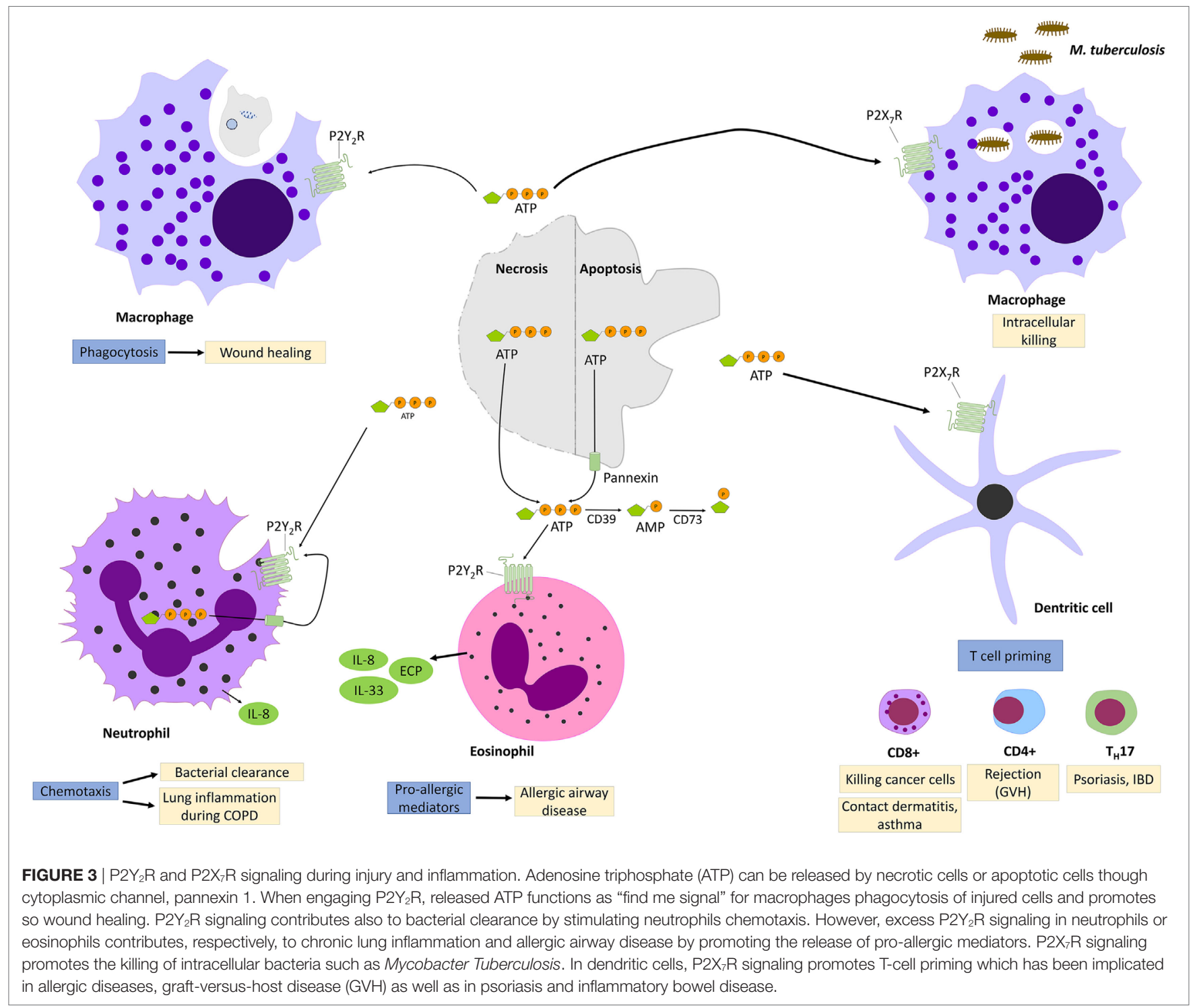


by activating $\mathrm{P} 2 \mathrm{X} 7$ receptors in monocytes/macrophages, which results in a cascade of events promoting bacterial killing including ROS generation via NOX2 (70), improvement of phagosomes and lysosomes fusion (72) and apoptosis (169). Furthermore, loss of function of P2X7R was associated with increase susceptibility to tuberculosis or toxoplasma infection (170). In addition to its beneficial effect for the clearance of bacteria and parasites, it has been shown that ATP-P2X7 axis was also involved in tumor suppression (171). Several studies demonstrated that ATP was released from dying cancer cells and activated dendritic cells via P2X7 signaling, which then triggered NLRP3 inflammasome activation resulting in the secretion of IL-1 $\beta$ (171). IL-1 $\beta$ then primed IFN-gamma-producing CD8 $+\mathrm{T}$ cells, thus promoting the clearance of cancer cells.

Despite its important role in regulating appropriate inflammatory and immunological response against invasive pathogens or cancer cells, it becomes increasingly clear that inappropriate activation of ATP-P2X7 axis contribute to chronic inflammatory diseases.

Indeed, as already mentioned, P2X7R activation by extracellular ATP elicits NLRP3 inflammasome activation (172). Furthermore, it has been shown in various experimental studies using cellular model of allergic disorders (83) and inflammatory bowel disease (173) that ATP-mediated P2X7 signaling in dendritic cells resulted in $\mathrm{T}$ cell priming, and therefore, promoting a chronic inflammatory state.

\section{Mitochondrial Transcription Factor}

Mitochondrial transcription factor A (TFAM), a member of the high mobility group box (HMGB) family, is essential for maintenance of mtDNA. It can bind to mtDNA in a sequenceindependent manner and regulate both mitochondrial transcription initiation and mtDNA copy number $(91,174)$. Furthermore, it has been shown that TFAM constitutes an important regulator of mtDNA packaging into higher-order structures, namely nucleoids.

TFAM is stabilizing mtDNA through the formation of nucleoids. Several reports have demonstrated that TFAM can promote a pro-inflammatory response both intracellularly or when it is released into the extracellular space. West et al. (28) demonstrated that TFAM deficiency causes aberrant mtDNA packaging resulting in the cytosolic release of mtDNA, where it engages the DNA sensors sGAS and activates CGAS/STING pathway and IFN type I response. Interestingly, extracellular TFAM alone (90) or in presence of other DAMPs such as $\mathrm{N}$-formyl peptide (88) or CpG DNA (89) can synergistically enhances inflammatory cytokines secretion in immune cells. Moreover, it has been shown that TFAM remains associated with mtDNA when it is released from injured cells and amplifies TNF- $\alpha$ release from TLR9-expressing dendritic cells by engaging RAGE (89).

\section{N-Formyl Peptide fMet-Leu-Phy}

The N-formyl peptide (NFP) fMet-Leu-Phy is a very potent chemoattractant for immune cells $(93,175)$ and also acts on platelets (94). Chemoattractant formyl peptides are in the membrane of mitochondria and can be found in the extracellular milieu after cell membrane rupture or around dying cells.
$\mathrm{N}$-formyl peptides are also found in the membrane of bacteria. Once recognized by formyl peptide receptors (FPRs), a group of G protein-coupled chemoattractant receptors highly expressed on immune cells but also on platelets (94), NFP will participate in the clearance of damaged cells and host defense against bacterial infection (175-177). NFP can exert its chemoattractant effect on neutrophils either directly by binding to FPRs followed by an increase in intracellular Ca influx (175) or indirectly by inducing IL-8 secretion, another potent chemoattractant for neutrophils (88). Interestingly, co-stimulation with NFP and mtDNA has a synergistic effect on IL-8 secretion by neutrophils (13).

\section{Succinate}

Succinate is a metabolic intermediate generated in mitochondria via the TCA cycle that plays an essential role in mitochondria function. Recent studies suggest that succinate, in addition of its crucial role ATP production, can also act as DAMPs and induce inflammation (98).

Once released in the extracellular environment, succinate can bind to the G protein-coupled receptor GPR91 (also named SUCNR1) that is highly expressed on the surface of dendritic cells (97) as well as in mouse kidney, liver, spleen, and small intestine (178). GPR91 signaling cascade has not been fully elucidated yet, but studies on human embryonic kidney 293 cells and human monocyte-derived dendritic cells have shown that GPR91 stimulation by succinate results in inositol triphosphate (IP3) accumulation, calcium mobilization, and extracellular signal-regulated kinase (ERK) phosphorylation (178). Dendritic cells treated with succinate displayed enhanced migration and inflammatory cytokines production through GPR91 signaling (97). Moreover, succinate synergizes with TLR ligands such as LPS to enhance the production of pro-inflammatory cytokines in dendritic cells. Interestingly, Tannahill et al. demonstrated in a recent publication that succinate was able to stabilize hypoxiainducible factor-1 alpha (HIN- $\alpha)$, promoting inflammation in macrophages. Indeed, LPS-primed macrophages changed their core metabolism from oxidative phosphorylation to glycolysis which increased succinate level and IL- $1 \beta$ secretion mediated by stabilization of HIN- $\alpha$ by succinate (98). Inhibition of glycolysis suppressed LPS-induced IL- $1 \beta$ secretion but not TNF- $\alpha$ in mouse macrophage. Succinate was also reported to exacerbate inflammation by inducing the adaptive immune response. Indeed, succinate and antigen simultaneous exposition increased dendritic cells capacity for antigen-specific T cell activation (97).

\section{Cardiolipin (CL)}

Cardiolipin is a lipid dimer consisting of two phosphatidyl group bridged by glycerol localized in the inner mitochondrial membrane that plays a critical role in diverse range of mitochondrial functions including mitochondrial respiration and mitochondrial biogenesis $(179,180)$. In addition to its role in maintaining membrane potential and architecture, CL is known to provide essential structural and functional support to several proteins involved in mitochondrial bioenergetics, including cytochrome oxidase and cytochrome bcl $(181,182)$. Several reports have highlighted the close interaction between CL and cytochrome C. Indeed, ROS-mediated CL peroxidation causes the detachment 
of cytochrome $\mathrm{C}$ from the mitochondrial inner membrane and its release into the cytoplasm, where it induces apoptosis (183). Furthermore, it was reported that oxidized CL is translocated to the OMM, where it participates in formation of mitochondrial permeability transition pore, resulting in the cytosolic release of mitochondrial proapoptotic factors. Loss of CL or alterations in its acyl chain composition or CL peroxidation have all been associated with mitochondrial dysfunction present in human diseases such as ischemia, hypothyroidism, aging, and heart failure $(180,184)$. Several reports have suggested that cardiolipid may play a role in cell death. Indeed, it has been shown that during death receptor-mediated apoptosis, Fas-mediated, for example, CL moves from mitochondria to the cell surface where it is recognized by antiphospholipid antibodies $(185,186)$. Similarly to NFP and mtDNA, CL is present in bacteria, specifically in their cell wall, and is sequestered from the immune system in mammalian mitochondria. It was not such a surprise to show that CL can also induce inflammation by binding NLRP3 inflammasomes. Interference with CL synthesis has been shown to inhibit NLRP3 activation (101). To further support a role of cardiolipidin in the immune response, Dieude et al. demonstrated that CL can stimulate subset of CL-responsive $\gamma \delta$ T cells present in the spleen and liver of healthy mice mediated by CL presentation by CD1dbearing dendritic cells (102).

\section{Cytochrome-c}

Cytochrome-c, a nuclear encoded, small soluble electron carrier located in the inner mitochondrial membrane, transfers electrons from complex III to IV $(187,188)$. Cytochrome-c is essential for the mitochondrial respiratory function, and its maintenance inside the mitochondria appears to be critical since its cytosolic release results in cell apoptosis. Once released into the cytosol, cytochrome-c binds and activates the apoptotic protease activating factor-1, which allows ATP binding and results in the formation of the ring-like apoptosome. Apoptosomes through CARD binds, and enzymatically activates procaspases 9 , which will in turn activate effector caspase- $3,-6$, and -7 , resulting in cell apotosis (108).

Numerous studies (189) have shown that cytochrome-c is released into the cytosol and then the extracellular space after mitochondrial injury and represent a useful marker of tissue injury in a large variety of diseases. In addition of being a marker of tissue injury, it has been shown that extracellular cytochrome-c can display pro-inflammatory proprieties mediated by the activation of NF- $\mathrm{KB}$ and causing neutrophil and monocyte triggered inflammation (190).

\section{MITOCHONDRIAL DAMPS IN HUMAN DISEASES}

\section{Mitochondrial DNA}

\section{mtDNA a Biological Marker of Tissue Injury}

There is a growing body of literature demonstrating that circulating mtDNA levels are elevated in large variety of human diseases, including sepsis $(29-36,191,192)$, trauma, pulmonary embolism (193), liver failure $(53,54)$, stroke (57), and cancer (45-50).
Numerous recent clinical studies have suggested that mtDNA circulating level may represent a new biological marker of the severity of tissue injury for critical ill patient admitted with sever sepsis $(29-36,191,192)$, trauma $(13,31,36,39-42)$, myocardial infarction $(194,195)$, and cardiogenic shock (44) since a correlation between mtDNA levels, injury severity and outcome has frequently been observed $(30,32,36,39,41,192)$. Interestingly, Krychtiuk et al. (30) demonstrated not only that mtDNA levels were associated with mortality in critical ill patients but also that TLR9 expression in patients increase the association between mtDNA and mortality. Furthermore, it was demonstrated in a clinical study with trauma patients that mtDNA levels represented an independent predictor for the development of post-traumatic systemic inflammatory response (SIRS) (40).

\section{mtDNA in Chronic Inflammatory Disorders}

Increased mtDNA levels were also detected in plasma and body fluid of patients presenting with a chronic inflammatory disorder $(58,59,61)$. In patients with rheumatoid arthritis (RA) $(58,59)$, mtDNA increased in plasma and synovial fluid compared to healthy volunteers. Studies in animal model of RA demonstrated that both mtDNA intraarticular injection (59) or blockade of DNA degradation by using DNAse II deficient mice $(59,154)$ were associated with synovial cells activation and the development of chronic polyarthritis resembling to that of human RA. Together, these studies indicate that mtDNA is capable of inducing arthritis in vivo and may exacerbate inflammation by stimulating the release of pro-inflammatory cytokines, thereby creating a vicious cycle of sterile inflammation and cell destruction with further release of immunogenic mtDNA.

Although innate immunity plays a major role in the pathogenesis of systemic lupus erythematosus (SLE), recent reports have suggested that dysregulation of intra- and extracellular DNA degradation may be involved in human SLE $(196,197)$. Indeed, Caielli et al. were able to replicate their in vitro results by showing that not only neutrophils isolated from patient with SLE had an increase in oxidized mtDNA aggregates in their mitochondria compared to neutrophils from healthy patients or juvenile dermatomyositis patients but also that oxidized mtDNA represented an SLE autoantigen since they detected anti-oxidized mtDNA autoantibodies in SLE sera (60). Further supporting the role of mtDNA/anti-mtDNA antibodies in SLE, Wang et al. (62) detected the presence of mtDNA in NET secreted by neutrophils as well as anti-mtDNA antibodies in sera from SLE patients that correlated with the degree of IFN score and severity of nephritis. Altogether, these studies point to new biomarkers along with the classic anti-dsDNA autoantibodies that may correlate with patient degree of lupus nephritis as well as IFN inflammatory response.

\section{Adenosine Triphosphate ATP and Cancer}

Numerous studies have highlighted the importance of the immune response for the success of antineoplasic chemotherapies. In line with those evidences, recent studies have demonstrated that ATP released by dying cancer cell followed dendritic cell and inflammasome activation via P2X7R were critical steps for the success of the treatment of certain types of 
cancers $(80,81)$. Loss of function mutation of P2X7R in patients with chronic lymphatic leukemia (198) or breast cancer (171) are for example associated with increased risks of progression to metastatic disease state.

\section{ATP and Asthma and Allergic Reaction}

Human studies in patients with asthma suggest that ATP and purinergic signaling may contribute to the chronic inflammatory state of asthma. Analysis of bronchoalveolar lavage fluid in chronic asthma patients revealed increased extracellular ATP level (83) as well as upregulated P2X7R expression in airway macrophages (199) compared to healthy volunteers. In addition, human eosinophils isolated from asthmatic patients had also an increased P2X7 expression and released pro-allergic cytokines such as ECP and IL-8 in response to ATP simulation (166).

\section{ATP and Inflammatory Disorders}

A possible link between purinergic signaling and pathogenesis of psoriasis, a chronic skin disorder characterized by a Th17dependent autoimmune response has recently been suggested (200). In this study, an upregulation of P2X7R in nonlesional and lesional psoriatic skin was observed compared with skin from healthy volunteers. In addition, they could elicit a proinflammatory response via $\mathrm{P} 2 \mathrm{X} 7$ signaling by stimulating nonlesional psoriatic skin with ATP. Further studies have shown that purinergic signaling was also involved in inflammatory bowel diseases. Histological analyses of patients with Crohn's disease have implicated the mast cells as the major effectors of the chronic intestinal inflammatory state. Recently, it was shown on colonic specimens of patients with Crohn's disease, that $\mathrm{P} 2 \mathrm{X} 7 \mathrm{R}$ was upregulated in mast cells and that $\mathrm{P} 2 \mathrm{X} 7$ receptor blockade or gene deletion in mice decreased intestinal inflammation (173). ATP and purinergic signaling have also been implicated in lung inflammatory disorders. In a mice model of bleomycin-induced lung injury, ATP levels were increased in bronchoalveolar lavage fluid and intranasal ATP injection further enhanced bleomycin-induced lung inflammation that could be inhibited with apyrosis treatment or in P2X7R knockout mice (85). Furthermore, it was shown that chronic obstructive pulmonary disease (COPD) patients had elevated ATP level in their lung lavage fluid with highest ATP concentrations among heavy smokers compared to non-smokers COPD patients. In addition, they demonstrated that ATP levels correlated negatively with lung function and positively with bronchoalveolar lavage fluid neutrophils, suggesting that airway ATP may represent a biomarker for smoke induced lung injury.

\section{N-Formyl Peptide, Formyl-Met-Leu-Phe (fMLP)}

A recent study suggested that $\mathrm{MLP}$ released in context of trauma could be responsible for the respiratory failure associated with trauma. In this study, Wenceslau et al. measured an increase in fMLP levels in plasma from trauma patients with SIRS or sepsis compared to control trauma group (95). In addition, they observed that fMLP induced lung neutrophil infiltration when instilled intratracheally to rats and produced airway contraction mediated by the fMLP receptor (FPR) and mast cells when exposed to isolated airways. The importance of fMLP and its receptor FPR for appropriate chemotaxis and immune response against infection was demonstrated in patients with localized juvenile periodontitis (LJP) (96). Indeed, it was shown that neutrophils from LJP patients present a genetic alteration in the gene coding for FPR, which could explain the decreased chemotactic activity and higher susceptibility for infections that is reported in LJP patients.

\section{Succinate}

Extensive evidence from the literature suggests that mitochondria play an important role in the pathophysiology of pulmonary hypertension $(\mathrm{PH})$ with mitochondrial alteration being observed in pulmonary arteries and in the right ventricle in context of $\mathrm{PH}$ associated with a metabolic shift from mitochondrial oxidative phosphorylation to glycolysis (99). Interestingly, it was shown in a recent study using an animal model of $\mathrm{PH}$ that pulmonary artery banding increased GPR91 and p-Akt expression in cardiomyocytes and that succinate treatment further increased p-Akt levels and right ventricle hypertrophy $(99,100)$. Those results suggest that succinate-GPR91 signaling is involved in right ventricle hypertrophy secondary to $\mathrm{PH}$.

\section{Cardiolipin}

Under normal conditions CL constitutes only 1-2\% of alveolar surfactant but its level increases in animal model of lung injury $(201,202)$. The role played by surfactant composition and CL during lung injury was further underlined in a study from Ray et al. (103). Indeed, they demonstrated that CL levels were increased in bronchoalveolar lavage fluids from humans and mice with bacterial pneumonia. In addition, intratracheal instillation of CL in mice reproduces the clinical picture of pneumonia and impairs surface tension-lowering activity of the surfactant. Interestingly, this group identified and characterized the activity of a novel CL transporter, Atp8b1 that may play a role in the removal of $\mathrm{CL}$ from lung fluid. Mutation in Atp8b1 was associated with severe pneumonia in humans and mice.

\section{Cytochrome-c}

Extracellular release of cytochrome-c had been confirmed in various conditions characterized by cell death. Indeed, increased serum cytochrome-c level was reported in patients with myocardial infarction (109) as well as in patients with liver diseases $(110,111)$. In the oncology literature, cytochrome-c was reported both as prognostic markers in various cancers (112) and as a marker of apoptosis to monitor the efficiency of chemotherapyinduced cell death (113). Similar to mtDNA, cytochrome-c level are elevated in plasma of patients with SIRS compared to healthy volunteers and are associated with survival and organ dysfunction (114). Further supporting a possible role of cytochrome-c as a biomarker, it was shown that cytochrome-c levels were increased in patients with severe encephalopathy (115) as well as in patients on hemodialysis (116) and correlated, respectively, with patient's outcome and IL-6 levels.

\section{Concluding Remarks}

In this review, we discussed the function and molecular regulation of various mitochondrial DAMPs and their role in human 
diseases. This review highlighted the complexity of the interaction between mitochondria, inflammation, and the immune system. It has become increasingly evident that mitochondrial DAMPs play critical role in sterile inflammation and in various diseases such as those characterized by chronic inflammation. However, many questions remain unanswered. These include the mechanisms for mtDNA release to the outside of the cells and the origin of cell free circulating mtDNA, particularly in critical ill patients. Although, an increasing number of studies have demonstrated that mitochondrial DAMPs can be actively released by non-necrotic cells exposed to an external stimulation, the mechanism for extracellular release for example via MDVs or autophagy requires further clarification. Also, while our understanding of the function and regulation of each individual mitochondrial DAMPs is constantly improving, additional studies are warranted to clarify the biological relevance of the interactions between different mitochondrial DAMPs and other extracellular molecules. The interplay between the various DAMPs is also a key to mediate sterile inflammation. Although

\section{REFERENCES}

1. Matzinger P. The danger model: a renewed sense of self. Science (2002) 296:301-5. doi:10.1126/science.1071059

2. Chen GY, Nunez G. Sterile inflammation: sensing and reacting to damage. Nat Rev Immunol (2010) 10:826-37. doi:10.1038/nri2873

3. Scaffidi P, Misteli T, Bianchi ME. Release of chromatin protein HMGB1 by necrotic cells triggers inflammation. Nature (2002) 418:191-5. doi:10.1038/ nature 00858

4. Quintana FJ, Cohen IR. Heat shock proteins as endogenous adjuvants in sterile and septic inflammation. J Immunol (2005) 175:2777-82. doi:10.4049/ jimmunol.175.5.2777

5. Schroder K, Tschopp J. The inflammasomes. Cell (2010) 140:821-32. doi:10.1016/j.cell.2010.01.040

6. Lamkanfi M, Dixit VM. Mechanisms and functions of inflammasomes. Cell (2014) 157:1013-22. doi:10.1016/j.cell.2014.04.007

7. Thornberry NA, Bull HG, Calaycay JR, Chapman KT, Howard AD, Kostura MJ, et al. A novel heterodimeric cysteine protease is required for interleukin-1 beta processing in monocytes. Nature (1992) 356:768-74. doi: $10.1038 / 356768 \mathrm{a} 0$

8. Martinon F, Burns K, Tschopp J. The inflammasome: a molecular platform triggering activation of inflammatory caspases and processing of proIL-beta. Mol Cell (2002) 10:417-26. doi:10.1016/S1097-2765(02)00599-3

9. Guo H, Callaway JB, Ting JP. Inflammasomes: mechanism of action, role in disease, and therapeutics. Nat Med (2015) 21:677-87. doi:10.1038/nm.3893

10. Malik A, Kanneganti TD. Inflammasome activation and assembly at a glance. J Cell Sci (2017) 130:3955-63. doi:10.1242/jcs.207365

11. Patel MN, Carroll RG, Galvan-Pena S, Mills EL, Olden R, Triantafilou M, et al. Inflammasome priming in sterile inflammatory disease. Trends $\mathrm{Mol}$ Med (2017) 23:165-80. doi:10.1016/j.molmed.2016.12.007

12. Gray MW, Burger G, Lang BF. Mitochondrial evolution. Science (1999) 283:1476-81. doi:10.1126/science.283.5407.1476

13. Zhang Q, Raoof M, Chen Y, Sumi Y, Sursal T, Junger W, et al. Circulating mitochondrial DAMPs cause inflammatory responses to injury. Nature (2010) 464:104-7. doi:10.1038/nature08780

14. Itagaki K, Kaczmarek E, Lee YT, Tang IT, Isal B, Adibnia Y, et al. Mitochondrial DNA released by trauma induces neutrophil extracellular traps. PLoS One (2015) 10:e0120549. doi:10.1371/journal.pone.0120549

15. Zhang JZ, Liu Z, Liu J, Ren JX, Sun TS. Mitochondrial DNA induces inflammation and increases TLR9/NF-kappaB expression in lung tissue. Int J Mol Med (2014) 33:817-24. doi:10.3892/ijmm.2014.1650

16. Sun S, Sursal T, Adibnia Y, Zhao C, Zheng Y, Li H, et al. Mitochondrial DAMPs increase endothelial permeability through neutrophil dependent not discussed herein, DAMPs also frequently synergize with pathogen-associated molecular pattern.

Finally, therapeutic immunomodulation by targeting mitochondrial DAMPs and their signaling pathways is promising in various inflammatory and auto-immune diseases. The measurement of mitochondrial DAMPs in body fluids as a biological marker of disease may also be of utility and bear prognostic values.

\section{AUTHOR CONTRIBUTIONS}

SG wrote the manuscript, and JP edited and provided direction for the article.

\section{FUNDING}

This work was supported by the Gertrude Von Meissner Foundation under the Grant No. ME1060683 and the Ligue Pulmonaire Genevoise under the grant No. ME10922.

and independent pathways. PLoS One (2013) 8:e59989. doi:10.1371/journal. pone.0059989

17. Kaczmarek A, Vandenabeele P, Krysko DV. Necroptosis: the release of damage-associated molecular patterns and its physiological relevance. Immunity (2013) 38:209-23. doi:10.1016/j.immuni.2013.02.003

18. Linkermann A, Green DR. Necroptosis. N Engl J Med (2014) 370:455-65. doi:10.1056/NEJMra1310050

19. Islam MN, Das SR, Emin MT, Wei M, Sun L, Westphalen K, et al. Mitochondrial transfer from bone-marrow-derived stromal cells to pulmonary alveoli protects against acute lung injury. Nat Med (2012) 18:759-65. doi: $10.1038 / \mathrm{nm} .2736$

20. Spees JL, Olson SD, Whitney MJ, Prockop DJ. Mitochondrial transfer between cells can rescue aerobic respiration. Proc Natl Acad Sci U S A (2006) 103:1283-8. doi:10.1073/pnas.0510511103

21. Guescini M, Guidolin D, Vallorani L, Casadei L, Gioacchini AM, Tibollo P, et al. C2C12 myoblasts release micro-vesicles containing mtDNA and proteins involved in signal transduction. Exp Cell Res (2010) 316:1977-84. doi:10.1016/j.yexcr.2010.04.006

22. Guescini M, Genedani S, Stocchi V, Agnati LF. Astrocytes and Glioblastoma cells release exosomes carrying mtDNA. J Neural Transm (Vienna) (2010) 117:1-4. doi:10.1007/s00702-009-0288-8

23. Nakahira K, Haspel JA, Rathinam VA, Lee SJ, Dolinay T, Lam HC, et al. Autophagy proteins regulate innate immune responses by inhibiting the release of mitochondrial DNA mediated by the NALP3 inflammasome. Nat Immunol (2011) 12:222-30. doi:10.1038/ni.1980

24. Shimada K, Crother TR, Karlin J, Dagvadorj J, Chiba N, Chen S, et al. Oxidized mitochondrial DNA activates the NLRP3 inflammasome during apoptosis. Immunity (2012) 36:401-14. doi:10.1016/j. immuni.2012.01.009

25. Jabir MS, Hopkins L, Ritchie ND, Ullah I, Bayes HK, Li D, et al. Mitochondrial damage contributes to Pseudomonas aeruginosa activation of the inflammasome and is downregulated by autophagy. Autophagy (2015) 11:166-82. doi:10.4161/15548627.2014.981915

26. Rongvaux A, Jackson R, Harman CC, Li T, West AP, de Zoete MR, et al. Apoptotic caspases prevent the induction of type I interferons by mitochondrial DNA. Cell (2014) 159:1563-77. doi:10.1016/j.cell.2014. 11.037

27. White MJ, McArthur K, Metcalf D, Lane RM, Cambier JC, Herold MJ, et al. Apoptotic caspases suppress mtDNA-induced STING-mediated type I IFN production. Cell (2014) 159:1549-62. doi:10.1016/j.cell.2014.11.036

28. West AP, Khoury-Hanold W, Staron M, Tal MC, Pineda CM, Lang SM, et al. Mitochondrial DNA stress primes the antiviral innate immune response. Nature (2015) 520:553-7. doi:10.1038/nature14156 
29. Bhagirath VC, Dwivedi DJ, Liaw PC. Comparison of the proinflammatory and procoagulant properties of nuclear, mitochondrial, and bacterial DNA. Shock (2015) 44:265-71. doi:10.1097/SHK.0000000000000397

30. Krychtiuk KA, Ruhittel S, Hohensinner PJ, Koller L, Kaun C, Lenz M, et al. Mitochondrial DNA and toll-like receptor-9 are associated with mortality in critically ill patients. Crit Care Med (2015) 43:2633-41. doi:10.1097/ CCM.0000000000001311

31. Timmermans K, Kox M, Scheffer GJ, Pickkers P. Plasma nuclear and mitochondrial DNA levels, and markers of inflammation, shock, and organ damage in patients with septic shock. Shock (2016) 45:607-12. doi:10.1097/ SHK.0000000000000549

32. Schafer ST, Franken L, Adamzik M, Schumak B, Scherag A, Engler A, et al. Mitochondrial DNA: an endogenous trigger for immune paralysis. Anesthesiology (2016) 124:923-33. doi:10.1097/ALN.0000000000001008

33. Di Caro V, Walko TD III, Bola RA, Hong JD, Pang D, Hsue V, et al. Plasma mitochondrial DNA - a novel DAMP in pediatric sepsis. Shock (2016) 45: 506-11. doi:10.1097/SHK.0000000000000539

34. Garrabou G, Moren C, Lopez S, Tobias E, Cardellach F, Miro O, et al. The effects of sepsis on mitochondria. JInfect Dis (2012) 205:392-400. doi:10.1093/infdis/jir764

35. Kung CT, Hsiao SY, Tsai TC, Su CM, Chang WN, Huang CR, et al. Plasma nuclear and mitochondrial DNA levels as predictors of outcome in severe sepsis patients in the emergency room. J Transl Med (2012) 10:130. doi:10.1186/1479-5876-10-130

36. Yamanouchi S, Kudo D, Yamada M, Miyagawa N, Furukawa H, Kushimoto S. Plasma mitochondrial DNA levels in patients with trauma and severe sepsis: time course and the association with clinical status. JCrit Care (2013) 28:1027-31. doi:10.1016/j.jcrc.2013.05.006

37. $\mathrm{Lu} \mathrm{CH}$, Chang WN, Tsai NW, Chuang YC, Huang CR, Wang HC. The value of serial plasma nuclear and mitochondrial DNA levels in adult community-acquired bacterial meningitis. QJM (2010) 103:169-75. doi:10.1093/ qjmed/hcp201

38. Zhang Q, Itagaki K, Hauser CJ. Mitochondrial DNA is released by shock and activates neutrophils via p38 map kinase. Shock (2010) 34:55-9. doi:10.1097/SHK.0b013e3181cd8c08

39. Lam NY, Rainer TH, Chiu RW, Joynt GM, Lo YM. Plasma mitochondrial DNA concentrations after trauma. Clin Chem (2004) 50:213-6. doi:10.1373/ clinchem.2003.025783

40. Gu X, Yao Y, Wu G, Lv T, Luo L, Song Y. The plasma mitochondrial DNA is an independent predictor for post-traumatic systemic inflammatory response syndrome. PLoS One (2013) 8:e72834. doi:10.1371/journal.pone.0072834

41. Prikhodko AS, Shabanov AK, Zinovkina LA, Popova EN, Aznauryan MA, Lanina NO, et al. Pure mitochondrial DNA does not activate human neutrophils in vitro. Biochemistry (Mosc) (2015) 80:629-35. doi:10.1134/ S0006297915050168

42. Simmons JD, Lee YL, Mulekar S, Kuck JL, Brevard SB, Gonzalez RP, et al. Elevated levels of plasma mitochondrial DNA DAMPs are linked to clinical outcome in severely injured human subjects. Ann Surg (2013) 258:591-6. doi:10.1097/SLA.0b013e3182a4ea46

43. Hauser CJ, Sursal T, Rodriguez EK, Appleton PT, Zhang Q, Itagaki K. Mitochondrial damage associated molecular patterns from femoral reamings activate neutrophils through formyl peptide receptors and P44/42 MAP kinase. J Orthop Trauma (2010) 24:534-8. doi:10.1097/BOT. 0b013e3181ec4991

44. Omura T, Kushimoto S, Yamanouchi S, Kudo D, Miyagawa N. High-mobility group box 1 is associated with neurological outcome in patients with post-cardiac arrest syndrome after out-of-hospital cardiac arrest. J Intensive Care (2016) 4:37. doi:10.1186/s40560-016-0161-4

45. Chen T, He J, Shen L, Fang H, Nie H, Jin T, et al. The mitochondrial DNA 4,977-bp deletion and its implication in copy number alteration in colorectal cancer. BMC Med Genet (2011) 12:8. doi:10.1186/1471-2350-12-8

46. Hosgood HD III, Liu CS, Rothman N, Weinstein SJ, Bonner MR, Shen M, et al. Mitochondrial DNA copy number and lung cancer risk in a prospective cohort study. Carcinogenesis (2010) 31:847-9. doi:10.1093/carcin/bgq045

47. Lan Q, Lim U, Liu CS, Weinstein SJ, Chanock S, Bonner MR, et al. A prospective study of mitochondrial DNA copy number and risk of non-Hodgkin lymphoma. Blood (2008) 112:4247-9. doi:10.1182/blood-2008-05-157974

48. Lynch SM, Weinstein SJ, Virtamo J, Lan Q, Liu CS, Cheng WL, et al. Mitochondrial DNA copy number and pancreatic cancer in the alpha-tocopherol beta-carotene cancer prevention study. Cancer Prev Res (Phila) (2011) 4:1912-9. doi:10.1158/1940-6207.CAPR-11-0002

49. Shen J, Platek M, Mahasneh A, Ambrosone CB, Zhao H. Mitochondrial copy number and risk of breast cancer: a pilot study. Mitochondrion (2010) 10:62-8. doi:10.1016/j.mito.2009.09.004

50. Zhang Y, Qu Y, Gao K, Yang Q, Shi B, Hou P, et al. High copy number of mitochondrial DNA (mtDNA) predicts good prognosis in glioma patients. Am J Cancer Res (2015) 5:1207-16.

51. Xing J, Chen M, Wood CG, Lin J, Spitz MR, Ma J, et al. Mitochondrial DNA content: its genetic heritability and association with renal cell carcinoma. J Natl Cancer Inst (2008) 100:1104-12. doi:10.1093/jnci/djn213

52. Yamada S, Nomoto S, Fujii T, Kaneko T, Takeda S, Inoue S, et al. Correlation between copy number of mitochondrial DNA and clinico-pathologic parameters of hepatocellular carcinoma. Eur J Surg Oncol (2006) 32:303-7. doi:10.1016/j.ejso.2006.01.002

53. Marques PE, Amaral SS, Pires DA, Nogueira LL, Soriani FM, Lima BH, et al. Chemokines and mitochondrial products activate neutrophils to amplify organ injury during mouse acute liver failure. Hepatology (2012) 56:1971-82. doi:10.1002/hep.25801

54. McGill MR, Staggs VS, Sharpe MR, Lee WM, Jaeschke H, Acute Liver G. Failure study, serum mitochondrial biomarkers and damage-associated molecular patterns are higher in acetaminophen overdose patients with poor outcome. Hepatology (2014) 60:1336-45. doi:10.1002/hep.27265

55. Oka T, Hikoso S, Yamaguchi O, Taneike M, Takeda T, Tamai T, et al. Mitochondrial DNA that escapes from autophagy causes inflammation and heart failure. Nature (2012) 485:251-5. doi:10.1038/nature10992

56. Ding Z, Liu S, Wang X, Khaidakov M, Dai Y, Mehta JL. Oxidant stress in mitochondrial DNA damage, autophagy and inflammation in atherosclerosis. Sci Rep (2013) 3:1077. doi:10.1038/srep01077

57. Tsai NW, Lin TK, Chen SD, Chang WN, Wang HC, Yang TM, et al. The value of serial plasma nuclear and mitochondrial DNA levels in patients with acute ischemic stroke. Clin Chim Acta (2011) 412:476-9. doi:10.1016/j. cca.2010.11.036

58. Hajizadeh S, DeGroot J, TeKoppele JM, Tarkowski A, Collins LV. Extracellular mitochondrial DNA and oxidatively damaged DNA in synovial fluid of patients with rheumatoid arthritis. Arthritis Res Ther (2003) 5:R234-40. doi:10.1186/ar787

59. Collins LV, Hajizadeh S, Holme E, Jonsson IM, Tarkowski A. Endogenously oxidized mitochondrial DNA induces in vivo and in vitro inflammatory responses. J Leukoc Biol (2004) 75:995-1000. doi:10.1189/jlb.0703328

60. Caielli S, Athale S, Domic B, Murat E, Chandra M, Banchereau R, et al. Oxidized mitochondrial nucleoids released by neutrophils drive type I interferon production in human lupus. J Exp Med (2016) 213:697-713. doi:10.1084/jem.20151876

61. Lood C, Blanco LP, Purmalek MM, Carmona-Rivera C, De Ravin SS, Smith CK, et al. Neutrophil extracellular traps enriched in oxidized mitochondrial DNA are interferogenic and contribute to lupus-like disease. Nat Med (2016) 22:146-53. doi:10.1038/nm.4027

62. Wang H, Li T, Chen S, Gu Y, Ye S. Neutrophil extracellular trap mitochondrial DNA and its autoantibody in systemic lupus erythematosus and a proofof-concept trial of metformin. Arthritis Rheumatol (2015) 67:3190-200. doi:10.1002/art.39296

63. Bours MJ, Swennen EL, Di Virgilio F, Cronstein BN, Dagnelie PC. Adenosine 5 '-triphosphate and adenosine as endogenous signaling molecules in immunity and inflammation. Pharmacol Ther (2006) 112:358-404. doi:10.1016/j. pharmthera.2005.04.013

64. Miyabe K, Sakamoto N, Wu YH, Mori N, Sakamoto H. Effects of platelet release products on neutrophilic phagocytosis and complement receptors. Thromb Res (2004) 114:29-36. doi:10.1016/j.thromres.2004.04.003

65. Zalavary S, Grenegard M, Stendahl O, Bengtsson T. Platelets enhance $\mathrm{Fc}$ (gamma) receptor-mediated phagocytosis and respiratory burst in neutrophils: the role of purinergic modulation and actin polymerization. J Leukoc Biol (1996) 60:58-68. doi:10.1002/jlb.60.1.58

66. Melloni E, Pontremoli S, Salamino F, Sparatore B, Michetti M, Sacco O, et al. ATP induces the release of a neutral serine proteinase and enhances the production of superoxide anion in membranes from phorbol ester-activated neutrophils. J Biol Chem (1986) 261:11437-9.

67. Meshki J, Tuluc F, Bredetean O, Ding Z, Kunapuli SP. Molecular mechanism of nucleotide-induced primary granule release in human neutrophils: 
role for the P2Y2 receptor. Am J Physiol Cell Physiol (2004) 286:C264-71. doi:10.1152/ajpcell.00287.2003

68. Goepfert C, Sundberg C, Sevigny J, Enjyoji K, Hoshi T, Csizmadia E, et al. Disordered cellular migration and angiogenesis in cd39-null mice. Circulation (2001) 104:3109-15. doi:10.1161/hc5001.100663

69. Labasi JM, Petrushova N, Donovan C, McCurdy S, Lira P, Payette MM, et al. Absence of the P2X7 receptor alters leukocyte function and attenuates an inflammatory response. JImmunol (2002) 168:6436-45. doi:10.4049/ jimmunol.168.12.6436

70. Hewinson J, Moore SF, Glover C, Watts AG, MacKenzie AB. A key role for redox signaling in rapid P2X7 receptor-induced IL-1 beta processing in human monocytes. JImmunol (2008) 180:8410-20. doi:10.4049/ jimmunol.180.12.8410

71. Moore SF, MacKenzie AB. NADPH oxidase NOX2 mediates rapid cellular oxidation following ATP stimulation of endotoxin-primed macrophages. J Immunol (2009) 183:3302-8. doi:10.4049/jimmunol.0900394

72. Fairbairn IP, Stober CB, Kumararatne DS, Lammas DA. ATP-mediated killing of intracellular mycobacteria by macrophages is a $\mathrm{P} 2 \mathrm{X}(7)$-dependent process inducing bacterial death by phagosome-lysosome fusion. J Immunol (2001) 167:3300-7. doi:10.4049/jimmunol.167.6.3300

73. Jamieson GP, Snook MB, Thurlow PJ, Wiley JS. Extracellular ATP causes of loss of L-selectin from human lymphocytes via occupancy of P2Z purinocepters. J Cell Physiol (1996) 166:637-42. doi:10.1002/(SICI)10974652(199603) 166:3<637::AID-JCP19>3.0.CO;2-3

74. Padeh S, Cohen A, Roifman CM. ATP-induced activation of human B lymphocytes via P2-purinoceptors. J Immunol (1991) 146:1626-32.

75. Davis BK, Wen H, Ting JP. The inflammasome NLRs in immunity, inflammation, and associated diseases. Annu Rev Immunol (2011) 29:707-35. doi:10.1146/annurev-immunol-031210-101405

76. Rathinam VA, Vanaja SK, Fitzgerald KA. Regulation of inflammasome signaling. Nat Immunol (2012) 13:333-42. doi:10.1038/ni.2237

77. Lohman AW, Billaud M, Isakson BE. Mechanisms of ATP release and signalling in the blood vessel wall. Cardiovasc Res (2012) 95:269-80. doi:10.1093/ $\mathrm{cvr} / \mathrm{cvs} 187$

78. Grygorczyk R, Hanrahan JW. CFTR-independent ATP release from epithelial cells triggered by mechanical stimuli. Am J Physiol (1997) 272:C1058-66. doi:10.1152/ajpcell.1997.272.3.C1058

79. Hazama A, Shimizu T, Ando-Akatsuka Y, Hayashi S, Tanaka S, Maeno E, et al. Swelling-induced, CFTR-independent ATP release from a human epithelial cell line: lack of correlation with volume-sensitive cl(-) channels. J Gen Physiol (1999) 114:525-33. doi:10.1085/jgp.114.4.525

80. Ma Y, Adjemian S, Yang H, Catani JP, Hannani D, Martins I, et al. ATPdependent recruitment, survival and differentiation of dendritic cell precursors in the tumor bed after anticancer chemotherapy. Oncoimmunology (2013) 2:e24568. doi:10.4161/onci.24568

81. Michaud M, Martins I, Sukkurwala AQ, Adjemian S, Ma Y, Pellegatti P, et al. Autophagy-dependent anticancer immune responses induced by chemotherapeutic agents in mice. Science (2011) 334:1573-7. doi:10.1126/ science. 1208347

82. Kouzaki H, Iijima K, Kobayashi T, O'Grady SM, Kita H. The danger signal, extracellular ATP, is a sensor for an airborne allergen and triggers IL-33 release and innate Th2-type responses. JImmunol (2011) 186:4375-87. doi:10.4049/jimmunol.1003020

83. Idzko M, Hammad H, van Nimwegen M, Kool M, Willart MA, Muskens F, et al. Extracellular ATP triggers and maintains asthmatic airway inflammation by activating dendritic cells. Nat Med (2007) 13:913-9. doi:10.1038/ $\mathrm{nm} 1617$

84. Wilhelm K, Ganesan J, Muller T, Durr C, Grimm M, Beilhack A, et al. Graftversus-host disease is enhanced by extracellular ATP activating P2X7R. Nat Med (2010) 16:1434-8. doi:10.1038/nm.2242

85. Riteau N, Gasse P, Fauconnier L, Gombault A, Couegnat M, Fick L, et al. Extracellular ATP is a danger signal activating P2X7 receptor in lung inflammation and fibrosis. Am J Respir Crit Care Med (2010) 182:774-83. doi:10.1164/rccm.201003-0359OC

86. Lommatzsch M, Cicko S, Muller T, Lucattelli M, Bratke K, Stoll P, et al. Extracellular adenosine triphosphate and chronic obstructive pulmonary disease. Am J Respir Crit Care Med (2010) 181:928-34. doi:10.1164/rccm. 200910-1506OC
87. Esther CR Jr, Alexis NE, Clas ML, Lazarowski ER, Donaldson SH, Ribeiro CM, et al. Extracellular purines are biomarkers of neutrophilic airway inflammation. Eur Respir J (2008) 31:949-56. doi:10.1183/09031936. 00089807

88. Crouser ED, Shao G, Julian MW, Macre JE, Shadel GS, Tridandapani S, et al. Monocyte activation by necrotic cells is promoted by mitochondrial proteins and formyl peptide receptors. Crit Care Med (2009) 37:2000-9. doi:10.1097/ CCM.0b013e3181a001ae

89. Julian MW, Shao G, Vangundy ZC, Papenfuss TL, Crouser ED. Mitochondrial transcription factor $\mathrm{A}$, an endogenous danger signal, promotes TNFalpha release via RAGE- and TLR9-responsive plasmacytoid dendritic cells. PLoS One (2013) 8:e72354. doi:10.1371/journal.pone.0072354

90. Chaung WW, Wu R, Ji Y, Dong W, Wang P. Mitochondrial transcription factor A is a proinflammatory mediator in hemorrhagic shock. Int J Mol Med (2012) 30:199-203. doi:10.3892/ijmm.2012.959

91. Kang D, Kim SH, Hamasaki N. Mitochondrial transcription factor A (TFAM): roles in maintenance of mtDNA and cellular functions. Mitochondrion (2007) 7:39-44. doi:10.1016/j.mito.2006.11.017

92. Remels AH, Schrauwen P, Broekhuizen R, Willems J, Kersten S, Gosker $\mathrm{HR}$, et al. Peroxisome proliferator-activated receptor expression is reduced in skeletal muscle in COPD. Eur Respir J (2007) 30:245-52. doi:10.1183/ 09031936.00144106

93. Carp H. Mitochondrial N-formylmethionyl proteins as chemoattractants for neutrophils. J Exp Med (1982) 155:264-75. doi:10.1084/jem.155.1.264

94. Czapiga M, Gao JL, Kirk A, Lekstrom-Himes J. Human platelets exhibit chemotaxis using functional $\mathrm{N}$-formyl peptide receptors. Exp Hematol (2005) 33:73-84. doi:10.1016/j.exphem.2004.09.010

95. Wenceslau CF, Szasz T, McCarthy CG, Baban B, NeSmith E, Webb RC. Mitochondrial N-formyl peptides cause airway contraction and lung neutrophil infiltration via formyl peptide receptor activation. Pulm Pharmacol Ther (2016) 37:49-56. doi:10.1016/j.pupt.2016.02.005

96. Gwinn MR, Sharma A, De Nardin E. Single nucleotide polymorphisms of the $\mathrm{N}$-formyl peptide receptor in localized juvenile periodontitis. J Periodontol (1999) 70:1194-201. doi:10.1902/jop.1999.70.10.1194

97. Rubic T, Lametschwandtner G, Jost S, Hinteregger S, Kund J, CarballidoPerrig N, et al. Triggering the succinate receptor GPR91 on dendritic cells enhances immunity. Nat Immunol (2008) 9:1261-9. doi:10.1038/ni.1657

98. Tannahill GM, Curtis AM, Adamik J, Palsson-McDermott EM, McGettrick AF, Goel G, et al. Succinate is an inflammatory signal that induces IL-1beta through HIF-1alpha. Nature (2013) 496:238-42. doi:10.1038/nature11986

99. Freund-Michel V, Khoyrattee N, Savineau JP, Muller B, Guibert C. Mitochondria: roles in pulmonary hypertension. Int J Biochem Cell Biol (2014) 55:93-7. doi:10.1016/j.biocel.2014.08.012

100. Yang L, Yu D, Fan HH, Feng Y, Hu L, Zhang WY, et al. Triggering the succinate receptor GPR91 enhances pressure overload-induced right ventricular hypertrophy. Int J Clin Exp Pathol (2014) 7:5415-28.

101. Iyer SS, He Q, Janczy JR, Elliott EI, Zhong Z, Olivier AK, et al. Mitochondrial cardiolipin is required for Nlrp3 inflammasome activation. Immunity (2013) 39:311-23. doi:10.1016/j.immuni.2013.08.001

102. Dieude M, Striegl H, Tyznik AJ, Wang J, Behar SM, Piccirillo CA, et al. Cardiolipin binds to CD1d and stimulates CD1d-restricted gammadelta $\mathrm{T}$ cells in the normal murine repertoire. JImmunol (2011) 186:4771-81. doi:10.4049/jimmunol.1000921

103. Ray NB, Durairaj L, Chen BB, McVerry BJ, Ryan AJ, Donahoe M, et al. Dynamic regulation of cardiolipin by the lipid pump Atp8b1 determines the severity of lung injury in experimental pneumonia. Nat Med (2010) 16:1120-7. doi:10.1038/nm.2213

104. Lusuardi M, Capelli A, Carli S, Tacconi MT, Salmona M, Donner CF. Role of surfactant in chronic obstructive pulmonary disease: therapeutic implications. Respiration (1992) 59(Suppl 1):28-32.

105. Codina R, Vanasse A, Kelekar A, Vezys V, Jemmerson R. Cytochrome c-induced lymphocyte death from the outside in: inhibition by serum leucine-rich alpha-2-glycoprotein-1. Apoptosis (2010) 15:139-52. doi:10.1007/ s10495-009-0412-0

106. Ahlemeyer B, Klumpp S, Krieglstein J. Release of cytochrome $\mathrm{c}$ into the extracellular space contributes to neuronal apoptosis induced by staurosporine. Brain Res (2002) 934:107-16. doi:10.1016/S0006-8993(02)02365-X 
107. Jemmerson R, LaPlante B, Treeful A. Release of intact, monomeric cytochrome c from apoptotic and necrotic cells. Cell Death Differ (2002) 9:538-48. doi:10.1038/sj.cdd.4400981

108. Li P, Nijhawan D, Budihardjo I, Srinivasula SM, Ahmad M, Alnemri ES, et al. Cytochrome $c$ and dATP-dependent formation of Apaf-1/caspase-9 complex initiates an apoptotic protease cascade. Cell (1997) 91:479-89. doi:10.1016/ S0092-8674(00)80434-1

109. Alleyne T, Joseph J, Sampson V. Cytochrome-c detection: a diagnostic marker for myocardial infarction. Appl Biochem Biotechnol (2001) 90:97-105. doi:10.1385/ABAB:90:2:97

110. Ben-Ari Z, Schmilovotz-Weiss H, Belinki A, Pappo O, Sulkes J, Neuman MG, et al. Circulating soluble cytochrome $c$ in liver disease as a marker of apoptosis. J Intern Med (2003) 254:168-75. doi:10.1046/j.1365-2796.2003. 01171.x

111. Sakaida I, Kimura T, Yamasaki T, Fukumoto Y, Watanabe K, Aoyama M, et al. Cytochrome $\mathrm{c}$ is a possible new marker for fulminant hepatitis in humans. J Gastroenterol (2005) 40:179-85. doi:10.1007/s00535-004-1517-4

112. Osaka A, Hasegawa H, Yamada Y, Yanagihara K, Hayashi T, Mine M, et al. A novel role of serum cytochrome $c$ as a tumor marker in patients with operable cancer. J Cancer Res Clin Oncol (2009) 135:371-7. doi:10.1007/ s00432-008-0479-y

113. Javid J, Mir R, Julka PK, Ray PC, Saxena A. Extracellular cytochrome c as a biomarker for monitoring therapeutic efficacy and prognosis of non-small cell lung cancer patients. Tumour Biol (2015) 36:4253-60. doi:10.1007/ s13277-015-3062-6

114. Adachi N, Hirota M, Hamaguchi M, Okamoto K, Watanabe K, Endo F. Serum cytochrome c level as a prognostic indicator in patients with systemic inflammatory response syndrome. Clin Chim Acta (2004) 342:127-36. doi:10.1016/j.cccn.2003.12.011

115. Hosoya M, Kawasaki Y, Katayose M, Sakuma H, Watanabe M, Igarashi E, et al. Prognostic predictive values of serum cytochrome c, cytokines, and other laboratory measurements in acute encephalopathy with multiple organ failure. Arch Dis Child (2006) 91:469-72. doi:10.1136/adc.2005.078436

116. Eleftheriadis T, Pissas G, Antoniadi G, Liakopoulos V, Stefanidis I. Damageassociated molecular patterns derived from mitochondria may contribute to the hemodialysis-associated inflammation. Int Urol Nephrol (2014) 46: 107-12. doi:10.1007/s11255-013-0417-z

117. Nakahira K, Hisata S, Choi AM. The roles of mitochondrial damageassociated molecular patterns in diseases. Antioxid Redox Signal (2015) 23:1329-50. doi:10.1089/ars.2015.6407

118. Andersson SG, Karlberg O, Canback B, Kurland CG. On the origin of mitochondria: a genomics perspective. Philos Trans $R$ Soc Lond B Biol Sci (2003) 358:165-77. doi:10.1098/rstb.2002.1193

119. Taanman JW. The mitochondrial genome: structure, transcription, translation and replication. Biochim Biophys Acta (1999) 1410:103-23. doi:10.1016/ S0005-2728(98)00161-3

120. Hemmi H, Takeuchi O, Kawai T, Kaisho T, Sato S, Sanjo H, et al. A toll-like receptor recognizes bacterial DNA. Nature (2000) 408:740-5. doi:10.1038/ 35047123

121. Krieg AM. CpG motifs in bacterial DNA and their immune effects. Annu Rev Immunol(2002)20:709-60.doi:10.1146/annurev.immunol.20.100301.064842

122. Lund J, Sato A, Akira S, Medzhitov R, Iwasaki A. Toll-like receptor 9-mediated recognition of Herpes simplex virus- 2 by plasmacytoid dendritic cells. J Exp Med (2003) 198:513-20. doi:10.1084/jem.20030162

123. Latz E, Schoenemeyer A, Visintin A, Fitzgerald KA, Monks BG, Knetter CF, et al. TLR9 signals after translocating from the ER to CpG DNA in the lysosome. Nat Immunol (2004) 5:190-8. doi:10.1038/ni1028

124. Sasai M, Linehan MM, Iwasaki A. Bifurcation of Toll-like receptor 9 signaling by adaptor protein 3. Science (2010) 329:1530-4. doi:10.1126/science. 1187029

125. Wei X, Shao B, He Z, Ye T, Luo M, Sang Y, et al. Cationic nanocarriers induce cell necrosis through impairment of $\mathrm{Na}(+) / \mathrm{K}(+)$-ATPase and cause subsequent inflammatory response. Cell Res (2015) 25:237-53. doi:10.1038/ cr.2015.9

126. Gu X, Wu G, Yao Y, Zeng J, Shi D, Lv T, et al. Intratracheal administration of mitochondrial DNA directly provokes lung inflammation through the TLR9-p38 MAPK pathway. Free Radic Biol Med (2015) 83:149-58. doi:10.1016/j.freeradbiomed.2015.02.034
127. Gurung $\mathrm{P}$, Kanneganti TD. Novel roles for caspase- 8 in IL-1beta and inflammasome regulation. Am J Pathol (2015) 185:17-25. doi:10.1016/j. ajpath.2014.08.025

128. Gross O, Thomas CJ, Guarda G, Tschopp J. The inflammasome: an integrated view.ImmunolRev(2011) 243:136-51.doi:10.1111/j.1600-065X.2011.01046.x

129. Zhou R, Yazdi AS, Menu P, Tschopp J. A role for mitochondria in NLRP3 inflammasome activation. Nature (2011) 469:221-5. doi:10.1038/nature09663

130. Ludlow LE, Johnstone RW, Clarke CJ. The HIN-200 family: more than interferon-inducible genes? Exp Cell Res (2005) 308:1-17. doi:10.1016/j. yexcr.2005.03.032

131. Hornung V, Ablasser A, Charrel-Dennis M, Bauernfeind F, Horvath G, Caffrey DR, et al. AIM2 recognizes cytosolic dsDNA and forms a caspase-1-activating inflammasome with ASC. Nature (2009) 458:514-8. doi: $10.1038 /$ nature 07725

132. Roberts TL, Idris A, Dunn JA, Kelly GM, Burnton CM, Hodgson S, et al. HIN-200 proteins regulate caspase activation in response to foreign cytoplasmic DNA. Science (2009) 323:1057-60. doi:10.1126/science.1169841

133. Yu J, Nagasu H, Murakami T, Hoang H, Broderick L, Hoffman HM, et al. Inflammasome activation leads to Caspase-1-dependent mitochondrial damage and block of mitophagy. Proc Natl Acad Sci U S A (2014) 111: 15514-9. doi:10.1073/pnas.1414859111

134. Barber GN. STING: infection, inflammation and cancer. Nat Rev Immunol (2015) 15:760-70. doi:10.1038/nri3921

135. Barber GN. STING-dependent cytosolic DNA sensing pathways. Trends Immunol (2014) 35:88-93. doi:10.1016/j.it.2013.10.010

136. Roers A, Hiller B, Hornung V. Recognition of endogenous nucleic acids by the innate immune system. Immunity (2016) 44:739-54. doi:10.1016/j. immuni.2016.04.002

137. Schneider WM, Chevillotte MD, Rice CM. Interferon-stimulated genes: a complex web of host defenses. Annu Rev Immunol (2014) 32:513-45. doi:10.1146/annurev-immunol-032713-120231

138. Hunter DR, Haworth RA. The Ca2+-induced membrane transition in mitochondria. I. The protective mechanisms. Arch Biochem Biophys (1979) 195:453-9. doi:10.1016/0003-9861(79)90371-0

139. Hunter DR, Haworth RA. The Ca2+-induced membrane transition in mitochondria. III. Transitional Ca2+ release. Arch Biochem Biophys (1979) 195:468-77. doi:10.1016/0003-9861(79)90373-4

140. Haworth RA, Hunter DR. The Ca2+-induced membrane transition in mitochondria. II. Nature of the Ca2+ trigger site. Arch Biochem Biophys (1979) 195:460-7. doi:10.1016/0003-9861(79)90372-2

141. Patrushev M, Kasymov V, Patrusheva V, Ushakova T, Gogvadze V, Gaziev A. Mitochondrial permeability transition triggers the release of mtDNA fragments. Cell Mol Life Sci (2004) 61:3100-3. doi:10.1007/s00018-004-4424-1

142. Neuspiel M, Schauss AC, Braschi E, Zunino R, Rippstein P, Rachubinski RA, et al. Cargo-selected transport from the mitochondria to peroxisomes is mediated by vesicular carriers. Curr Biol (2008) 18:102-8. doi:10.1016/j. cub.2007.12.038

143. Soubannier V, Rippstein P, Kaufman BA, Shoubridge EA, McBride HM. Reconstitution of mitochondria derived vesicle formation demonstrates selective enrichment of oxidized cargo. PLoS One (2012) 7:e52830. doi:10.1371/journal.pone.0052830

144. Soubannier V, McLelland GL, Zunino R, Braschi E, Rippstein P, Fon EA, et al. A vesicular transport pathway shuttles cargo from mitochondria to lysosomes. Curr Biol (2012) 22:135-41. doi:10.1016/j.cub.2011.11.057

145. McLelland GL, Soubannier V, Chen CX, McBride HM, Fon EA. Parkin and PINK1 function in a vesicular trafficking pathway regulating mitochondrial quality control. EMBO J (2014) 33:282-95. doi:10.1002/ embj.201385902

146. Sugiura A, McLelland GL, Fon EA, McBride HM. A new pathway for mitochondrial quality control: mitochondrial-derived vesicles. EMBO J (2014) 33:2142-56. doi:10.15252/embj.201488104

147. Maeda A, Fadeel B. Mitochondria released by cells undergoing TNF-alphainduced necroptosis act as danger signals. Cell Death Dis (2014) 5:e1312. doi:10.1038/cddis.2014.277

148. Qing DY, Conegliano D, Shashaty MG, Seo J, Reilly JP, Worthen GS, et al. Red blood cells induce necroptosis of lung endothelial cells and increase susceptibility to lung inflammation. Am J Respir Crit Care Med (2014) 190:1243-54. doi:10.1164/rccm.201406-1095OC 
149. Degterev A, Huang Z, Boyce M, Li Y, Jagtap P, Mizushima N, et al. Chemical inhibitor of nonapoptotic cell death with therapeutic potential for ischemic brain injury. Nat Chem Biol (2005) 1:112-9. doi:10.1038/nchembio711

150. Degterev A, Hitomi J, Germscheid M, Ch'en IL, Korkina O, Teng X, et al. Identification of RIP1 kinase as a specific cellular target of necrostatins. Nat Chem Biol (2008) 4:313-21. doi:10.1038/nchembio.83

151. Zhang DW, Shao J, Lin J, Zhang N, Lu BJ, Lin SC, et al. RIP3, an energy metabolism regulator that switches TNF-induced cell death from apoptosis to necrosis. Science (2009) 325:332-6. doi:10.1126/science.1172308

152. Boudreau LH, Duchez AC, Cloutier N, Soulet D, Martin N, Bollinger J, et al. Platelets release mitochondria serving as substrate for bactericidal group IIA-secreted phospholipase A2 to promote inflammation. Blood (2014) 124:2173-83. doi:10.1182/blood-2014-05-573543

153. Green DR, Galluzzi L, Kroemer G. Mitochondria and the autophagyinflammation-cell death axis in organismal aging. Science (2011) 333: 1109-12. doi:10.1126/science.1201940

154. Kawane K, Ohtani M, Miwa K, Kizawa T, Kanbara Y, Yoshioka Y, et al. Chronic polyarthritis caused by mammalian DNA that escapes from degradation in macrophages. Nature (2006) 443:998-1002. doi:10.1038/nature05245

155. Deshmukh SD, Kremer B, Freudenberg M, Bauer S, Golenbock DT, HennekeP. Macrophages recognize streptococci through bacterial single-stranded RNA. EMBO Rep (2011) 12:71-6. doi:10.1038/embor.2010.189

156. Eberle F, Sirin M, Binder M, Dalpke AH. Bacterial RNA is recognized by different sets of immunoreceptors. Eur JImmunol (2009) 39:2537-47. doi:10.1002/eji.200838978

157. Kariko K, Buckstein M, Ni H, Weissman D. Suppression of RNA recognition by toll-like receptors: the impact of nucleoside modification and the evolutionary origin of RNA. Immunity (2005) 23:165-75. doi:10.1016/j. immuni.2005.06.008

158. Mancuso G, Gambuzza M, Midiri A, Biondo C, Papasergi S, Akira S, et al. Bacterial recognition by TLR7 in the lysosomes of conventional dendritic cells. Nat Immunol (2009) 10:587-94. doi:10.1038/ni.1733

159. Gehrig S, Eberle ME, Botschen F, Rimbach K, Eberle F, Eigenbrod T, et al. Identification of modifications in microbial, native tRNA that suppress immunostimulatory activity. J Exp Med (2012) 209:225-33. doi:10.1084/ jem.20111044

160. Kruger A, Oldenburg M, Chebrolu C, Beisser D, Kolter J, Sigmund AM, et al. Human TLR8 senses UR/URR motifs in bacterial and mitochondrial RNA. EMBO Rep (2015) 16:1656-63. doi:10.15252/embr.201540861

161. Sha W, Mitoma H, Hanabuchi S, Bao M, Weng L, Sugimoto N, et al. Human NLRP3 inflammasome senses multiple types of bacterial RNAs. Proc Natl Acad Sci U S A (2014) 111:16059-64. doi:10.1073/pnas.1412487111

162. Burnstock G. Pathophysiology and therapeutic potential of purinergic signaling. Pharmacol Rev (2006) 58:58-86. doi:10.1124/pr.58.1.5

163. Elliott MR, Chekeni FB, Trampont PC, Lazarowski ER, Kadl A, Walk $\mathrm{SF}$, et al. Nucleotides released by apoptotic cells act as a find-me signal to promote phagocytic clearance. Nature (2009) 461:282-6. doi:10.1038/ nature08296

164. Chekeni FB, Elliott MR, Sandilos JK, Walk SF, Kinchen JM, Lazarowski ER, et al. Pannexin 1 channels mediate 'find-me' signal release and membrane permeability during apoptosis. Nature (2010) 467:863-7. doi:10.1038/ nature09413

165. Chen Y, Corriden R, Inoue Y, Yip L, Hashiguchi N, Zinkernagel A, et al. ATP release guides neutrophil chemotaxis via $\mathrm{P} 2 \mathrm{Y} 2$ and $\mathrm{A} 3$ receptors. Science (2006) 314:1792-5. doi:10.1126/science.1132559

166. Idzko M, Panther E, Bremer HC, Sorichter S, Luttmann W, Virchow CJ Jr, et al. Stimulation of $\mathrm{P} 2$ purinergic receptors induces the release of eosinophil cationic protein and interleukin-8 from human eosinophils. Br J Pharmacol (2003) 138:1244-50. doi:10.1038/sj.bjp.0705145

167. Khakh BS, Burnstock G, Kennedy C, King BF, North RA, Seguela P, et al. International union of pharmacology. XXIV. Current status of the nomenclature and properties of $\mathrm{P} 2 \mathrm{X}$ receptors and their subunits. Pharmacol Rev (2001) 53:107-18.

168. Surprenant A, North RA. Signaling at purinergic P2X receptors. Annu Rev Physiol (2009) 71:333-59. doi:10.1146/annurev.physiol.70.113006.100630

169. Placido R, Auricchio G, Falzoni S, Battistini L, Colizzi V, Brunetti E, et al. $\mathrm{P} 2 \mathrm{X}(7)$ purinergic receptors and extracellular ATP mediate apoptosis of human monocytes/macrophages infected with Mycobacterium tuberculosis reducing the intracellular bacterial viability. Cell Immunol (2006) 244:10-8. doi:10.1016/j.cellimm.2007.02.001

170. Coutinho-Silva R, Ojcius DM. Role of extracellular nucleotides in the immune response against intracellular bacteria and protozoan parasites. Microbes Infect (2012) 14:1271-7. doi:10.1016/j.micinf.2012.05.009

171. Ghiringhelli F, Apetoh L, Tesniere A, Aymeric L, Ma Y, Ortiz C, et al. Activation of the NLRP3 inflammasome in dendritic cells induces IL-1betadependent adaptive immunity against tumors. Nat Med (2009) 15:1170-8. doi: $10.1038 / \mathrm{nm} .2028$

172. Gombault A, Baron L, Couillin I. ATP release and purinergic signaling in NLRP3 inflammasome activation. Front Immunol (2012) 3:414. doi:10.3389/ fimmu.2012.00414

173. Kurashima Y,Amiya T,Nochi T, Fujisawa K, Haraguchi T, Iba H, etal. Extracellular ATP mediates mast cell-dependent intestinal inflammation through P2X7 purinoceptors. Nat Commun (2012) 3:1034. doi:10.1038/ncomms2023

174. Campbell CT, Kolesar JE, Kaufman BA. Mitochondrial transcription factor A regulates mitochondrial transcription initiation, DNA packaging, and genome copy number. Biochim Biophys Acta (2012) 1819:921-9. doi:10.1016/j.bbagrm.2012.03.002

175. Le Y, Murphy PM, Wang JM. Formyl-peptide receptors revisited. Trends Immunol (2002) 23:541-8. doi:10.1016/S1471-4906(02)02316-5

176. Dorward DA, Lucas CD, Chapman GB, Haslett C, Dhaliwal K, Rossi AG. The role of formylated peptides and formyl peptide receptor 1 in governing neutrophil function during acute inflammation. Am J Pathol (2015) 185:1172-84. doi:10.1016/j.ajpath.2015.01.020

177. Panaro MA, Acquafredda A, Sisto M, Lisi S, Maffione AB, Mitolo V. Biological role of the $\mathrm{N}$-formyl peptide receptors. Immunopharmacol Immunotoxicol (2006) 28:103-27. doi:10.1080/08923970600625975

178. He W, Miao FJ, Lin DC, Schwandner RT, Wang Z, Gao J, et al. Citric acid cycle intermediates as ligands for orphan G-protein-coupled receptors. Nature (2004) 429:188-93. doi:10.1038/nature02488

179. Claypool SM, Koehler CM. The complexity of cardiolipin in health and disease. Trends Biochem Sci (2012) 37:32-41. doi:10.1016/j.tibs.2011.09.003

180. Chicco AJ, Sparagna GC. Role of cardiolipin alterations in mitochondrial dysfunction and disease. Am J Physiol Cell Physiol (2007) 292:C33-44. doi:10.1152/ajpcell.00243.2006

181. Gomez B Jr, Robinson NC. Phospholipase digestion of bound cardiolipin reversibly inactivates bovine cytochrome bcl. Biochemistry (1999) 38: 9031-8. doi:10.1021/bi990603r

182. Eble KS, Coleman WB, Hantgan RR, Cunningham CC. Tightly associated cardiolipin in the bovine heart mitochondrial ATP synthase as analyzed by 31P nuclear magnetic resonance spectroscopy. J Biol Chem (1990) 265:19434-40.

183. Galluzzi L, Zamzami N, de La Motte Rouge T, Lemaire C, Brenner C, Kroemer G. Methods for the assessment of mitochondrial membrane permeabilization in apoptosis. Apoptosis (2007) 12:803-13. doi:10.1007/ s10495-007-0720-1

184. Paradies G, Paradies V, Ruggiero FM, Petrosillo G. Cardiolipin and mitochondrial function in health and disease. Antioxid Redox Signal (2014) 20:1925-53. doi:10.1089/ars.2013.5280

185. Sorice M, Circella A, Misasi R, Pittoni V, Garofalo T, Cirelli A, et al. Cardiolipin on the surface of apoptotic cells as a possible trigger for antiphospholipids antibodies. Clin Exp Immunol (2000) 122:277-84. doi:10.1046/j.1365-2249.2000.01353.x

186. Sorice M, Circella A, Cristea IM, Garofalo T, Di Renzo L, Alessandri C, et al. Cardiolipin and its metabolites move from mitochondria to other cellular membranes during death receptor-mediated apoptosis. Cell Death Differ (2004) 11:1133-45. doi:10.1038/sj.cdd.4401457

187. Kuhlbrandt W. Structure and function of mitochondrial membrane protein complexes. BMC Biol (2015) 13:89. doi:10.1186/s12915-015-0201-x

188. Hillier LW, Fulton RS, Fulton LA, Graves TA, Pepin KH, Wagner-McPherson C, et al. The DNA sequence of human chromosome 7. Nature (2003) 424:157-64. doi:10.1038/nature01782

189. Zager RA, Johnson AC, Hanson SY. Proximal tubular cytochrome c efflux: determinant, and potential marker, of mitochondrial injury. Kidney Int (2004) 65:2123-34. doi:10.1111/j.1523-1755.2004.00638.x

190. Pullerits R, Bokarewa M, Jonsson IM, Verdrengh M, Tarkowski A. Extracellular cytochrome c, a mitochondrial apoptosis-related protein, 
induces arthritis. Rheumatology (Oxford) (2005) 44:32-9. doi:10.1093/ rheumatology/keh406

191. Pyle A, Burn DJ, Gordon C, Swan C, Chinnery PF, Baudouin SV. Fall in circulating mononuclear cell mitochondrial DNA content in human sepsis. Intensive Care Med (2010) 36:956-62. doi:10.1007/s00134-010-1823-7

192. Nakahira K, Kyung SY, Rogers AJ, Gazourian L, Youn S, Massaro AF, et al. Circulating mitochondrial DNA in patients in the ICU as a marker of mortality: derivation and validation. PLoS Med (2013) 10:e1001577. doi:10.1371/ journal.pmed.1001577

193. Arnalich F, Codoceo R, Lopez-Collazo E, Montiel C. Circulating cell-free mitochondrial DNA: a better early prognostic marker in patients with out-of-hospital cardiac arrest. Resuscitation (2012) 83:e162-3. doi:10.1016/j. resuscitation.2012.03.032

194. Bliksoen M, Mariero LH, Ohm IK, Haugen F, Yndestad A, Solheim S, et al. Increased circulating mitochondrial DNA after myocardial infarction. Int J Cardiol (2012) 158:132-4. doi:10.1016/j.ijcard.2012.04.047

195. Qin C, Gu J, Liu R, Xu F, Qian H, He Q, et al. Release of mitochondrial DNA correlates with peak inflammatory cytokines in patients with acute myocardial infarction. Anatol J Cardiol (2017) 17:224-8. doi:10.14744/ AnatolJCardiol.2016.7209

196. Al-Mayouf SM, Sunker A, Abdwani R, Abrawi SA, Almurshedi F, Alhashmi N, et al. Loss-of-function variant in DNASE1L3 causes a familial form of systemic lupus erythematosus. Nat Genet (2011) 43:1186-8. doi:10.1038/ng.975

197. Crow YJ. Type I interferonopathies: a novel set of inborn errors of immunity. Ann N Y Acad Sci (2011) 1238:91-8. doi:10.1111/j.1749-6632.2011. 06220.x
198. Stagg J, Smyth MJ. Extracellular adenosine triphosphate and adenosine in cancer. Oncogene (2010) 29:5346-58. doi:10.1038/onc.2010.292

199. Muller T, Vieira RP, Grimm M, Durk T, Cicko S, Zeiser R, et al. A potential role for P2X7R in allergic airway inflammation in mice and humans. Am J Respir Cell Mol Biol (2011) 44:456-64. doi:10.1165/rcmb.20100129OC

200. Killeen ME, Ferris L, Kupetsky EA, Falo L Jr, Mathers AR. Signaling through purinergic receptors for ATP induces human cutaneous innate and adaptive Th17 responses: implications in the pathogenesis of psoriasis. J Immunol (2013) 190:4324-36. doi:10.4049/jimmunol.1202045

201. Ksenzenko SM, Davidson SB, Saba AA, Franko AP, Raafat AM, Diebel LN, et al. Effect of triiodothyronine augmentation on rat lung surfactant phospholipids during sepsis. J Appl Physiol (1985) 82(1997):2020-7. doi:10.1152/ jappl.1997.82.6.2020

202. Liau DF, Barrett CR, Bell AL, Cernansky G, Ryan SF. Diphosphatidylglycerol in experimental acute alveolar injury in the dog. J Lipid Res (1984) 25:678-83.

Conflict of Interest Statement: The authors declare that the research was conducted in the absence of any commercial or financial relationships that could be construed as a potential conflict of interest.

Copyright $(2018$ Grazioli and Pugin. This is an open-access article distributed under the terms of the Creative Commons Attribution License (CC BY). The use, distribution or reproduction in other forums is permitted, provided the original author(s) and the copyright owner are credited and that the original publication in this journal is cited, in accordance with accepted academic practice. No use, distribution or reproduction is permitted which does not comply with these terms. 